\title{
On the currents and transports connected with the atlantic meridional overturning circulation in the subpolar North Atlantic
}

\author{
X. Xu, ${ }^{1}$ H. E. Hurlburt, ${ }^{2}$ W. J. Schmitz Jr., ${ }^{3}$ R. Zantopp, ${ }^{4}$ J. Fischer, ${ }^{4}$ and P. J. Hogan ${ }^{2}$ \\ Received 27 June 2012; revised 15 December 2012; accepted 17 December 2012; published 31 January 2013.
}

[1] Results from an interannually forced, $0.08^{\circ}$ eddy-resolving simulation based on the Hybrid Coordinate Ocean Model, in conjunction with a small but well-determined transport database, are used to investigate the currents and transports associated with the Atlantic meridional overturning circulation (AMOC) in the subpolar North Atlantic (SPNA). The model results yield a consistent warming in the western SPNA since the early 1990s, along with mean transports similar to those observed for the trans-basin AMOC across the World Ocean Circulation Experiment hydrographic section AR19 (16.4 Sv) and boundary currents at the exit of the Labrador Sea near $53^{\circ} \mathrm{N}(39.0 \mathrm{~Sv})$ and east of the Grand Banks near $43^{\circ} \mathrm{N}(15.9 \mathrm{~Sv})$. Over a 34 year integration, the model-determined AMOC across the AR19 section and the western boundary current near $53^{\circ} \mathrm{N}$ both exhibit no systematic trend but some long-term (interannual and longer) variabilities, including a decadal transport variation of 3-4 Sv from relatively high in the 1990s to low in the 2000s. The decadal variability of the model boundary current transport near $53^{\circ} \mathrm{N}$ lags the observed winter time North Atlantic Oscillation index by about 2 years and leads the model AMOC across the AR19 section by about 1 year. The model results also show that the long-term variabilities are low compared to those on shorter time scales. Thus, rapid sampling of the current over long time intervals is required to filter out high-frequency variabilities in order to determine the lower frequency variabilities of interest.

Citation: Xu, X., H. E. Hurlburt, W. J. Schmitz Jr., R. Zantopp, J. Fischer, and P. J. Hogan (2013), On the currents and transports connected with the atlantic meridional overturning circulation in the subpolar North Atlantic, J. Geophys. Res. Oceans, 118, 502-516, doi:10.1002/jgrc.20065.

\section{Introduction}

[2] The subpolar North Atlantic (SPNA), here defined as the segment between the Greenland-Iceland-Scotland (GIS) Ridge and the World Ocean Circulation Experiment hydrographic section AR19 (average latitude of $\sim 46^{\circ} \mathrm{N}$, Figure 1), plays an important role in the deep water formation associated with the Atlantic meridional overturning circulation (AMOC) [e.g., Rhein et al., 2011]. The large-scale circulation in this area generally consists of three layers (Figure 2). In an upper layer, the North Atlantic Current (NAC), along with recirculations, carries warm and saline water from the Gulf Stream into the SPNA. An eastern branch of the NAC flows into the Nordic Seas and the Arctic Ocean. The majority of this water

\footnotetext{
${ }^{1}$ Department of Marine Science, University of Southern Mississippi, Stennis Space Center, Mississippi, USA.

${ }^{2}$ Oceanography Division, Naval Research Laboratory, Stennis Space Center, Mississippi, USA.

${ }^{3}$ Harte Research Institute, Texas A \& M University-Corpus Christi, Corpus Christi, Texas, USA.

${ }^{4}$ Helmholtz Centre for Ocean Research Kiel (GEOMAR), Kiel, Germany.

Corresponding author: X. Xu, Center for Ocean-Atmospheric Prediction Studies (COAPS), Florida State University (FSU), 2035 E. Paul Dirac Dr., 200 RM Johnson Bldg., Tallahassee, FL 32306-2840 USA. (xxu@coaps.fsu.edu)

(C)2013. American Geophysical Union. All Rights Reserved. 2169-9275/13/10.1002/jgrc.20065
}

flows back into the North Atlantic as dense Nordic Seas Overflow Water (NSOW) over the GIS Ridge [Hansen et al., 2008, Figure 1.15]. The western NAC branch recirculates around the subpolar basins cyclonically, becomes colder and fresher en route, and eventually transforms into Labrador Sea Water (LSW) through wintertime deep convection. NSOW and LSW, the primary water masses contributing to North Atlantic Deep Water (NADW) and the deep western boundary current (DWBC), constitute the deep and intermediate AMOC layers of interest here.

[3] The water masses in the western SPNA have undergone large, long-term changes in the past decades [e.g., Dickson et al., 2002; Lazier et al., 2002; Stramma et al., 2004; Avsic et al., 2006; Yashayaev, 2007; Sarafanov et al., 2007]. Quantifying the transport variation is a challenge [Schott and Brandt, 2007; Dickson et al., 2008], however. Transport variabilities often have been estimated based on hydrographic data, sometimes in conjunction with the sea surface height (SSH) data from satellite altimeters to obtain absolute velocities (thus transports) [e.g., Bacon, 1998; Han and Tang, 2001; Kieke and Rhein, 2006; Sarafanov et al., 2009; Sarafanov et al., 2010; Han et al., 2010]. For example, Han et al. [2010] estimated a decline of the boundary current transport by $6.3 \pm 1.5 \mathrm{~Sv}$ from $1993-1995$ to $1996-1999$ and a partial rebound of $3.2 \pm 1.7$ in the 2001-2004. The main difficulty, however, stems from the fact that currents observed in this area contain a high level of variability on eddy and other 


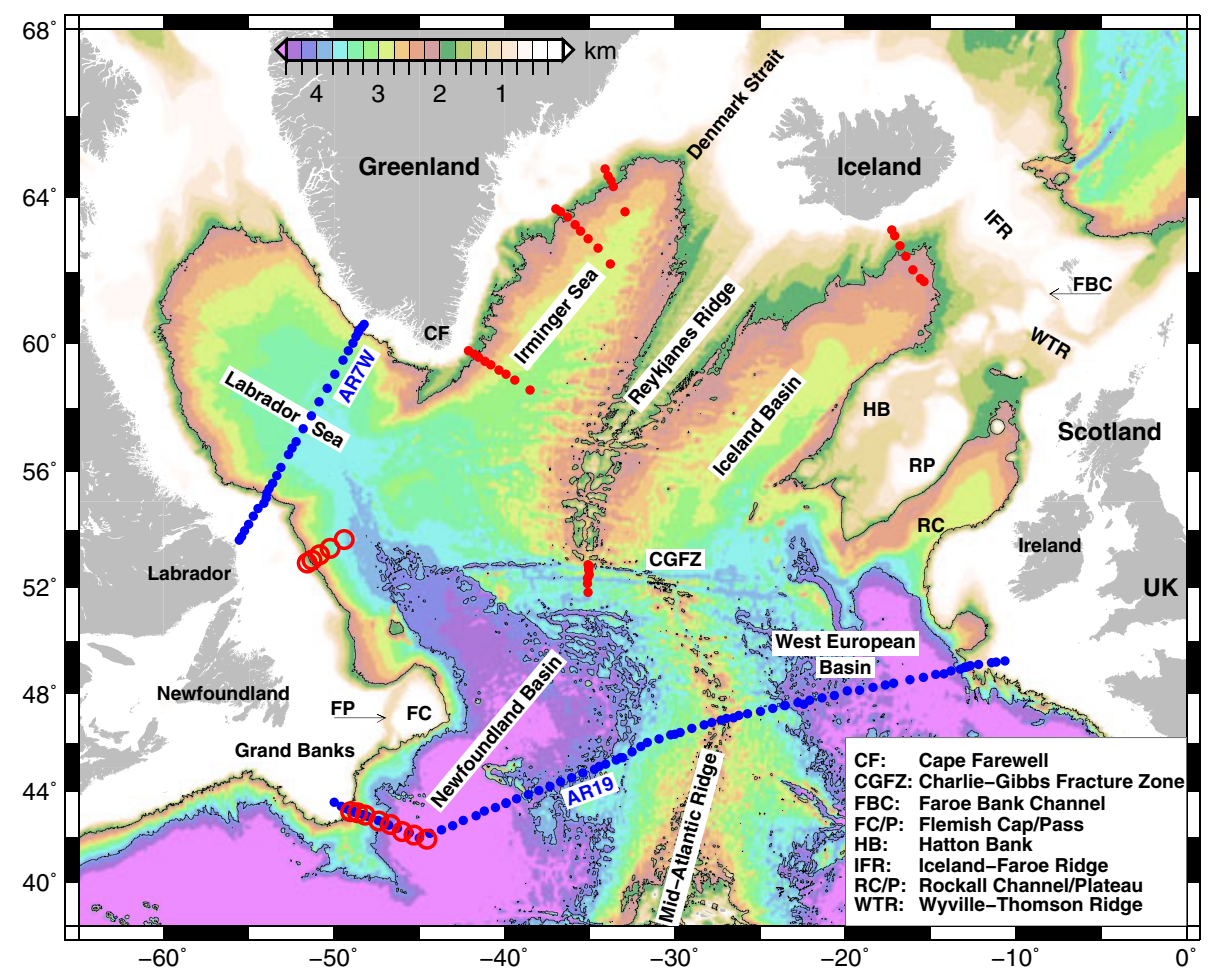

Figure 1. Bathymetry of the subpolar North Atlantic. Blue dots denote the hydrographic sections AR7W and AR19. Red dots denote locations of five long-term moored current meter arrays where overflow water transports have been observed [see $X u$ et al., 2010]. Red circles denote locations of long-term moored current meter arrays at the exit of the Labrador Sea, near $53^{\circ} \mathrm{N}$ [Fischer et al., 2004, 2010] and east of the Grand Banks, near $43^{\circ} \mathrm{N}$ [Clarke et al., 1998; Schott et al., 2004, 2006; Schott and Brandt, 2007].

comparably short-time scales [Fischer et al., 2004, 2010; Schott et al., 2004, 2006]. Thus, rapid sampling of the currents and time-averaging, not available from hydrographic data, are needed to filter out high-frequency variability for assessment of variations on interannual and longer time scales.

[4] Häkkinen and Rhines [2004, 2009], primarily from SSH data, suggest that the SPNA circulation has declined significantly from 1994 to 2003. A somewhat different change is depicted in Daniault et al. [2011], using data from altimetry and a 2 year moored current meter array. The boundary current transport southeast of Cape Farewell declined from 1997 to 2005, whereas it is nearly the same over 1993-1994 and 2002-2003. The annual mean transports in Daniault et al. [2011] have a small standard deviation $(1.0 \mathrm{~Sv})$ compared to the mean $(19.5 \mathrm{~Sv})$. Existing direct measurements of boundary currents in the western SPNA (see section 2) suggest that temporal variability is significantly lower on interannual and longer time scales than on short-time scales. Overall, a quantitative description of the low-frequency transport variability in the SPNA has remained unclear observationally.

[5] The variability of the SPNA circulation has received considerable attention in modeling studies with coarse and eddy-permitting resolutions [e.g., Hátún et al., 2005; Zhang, 2008; Lohmann et al., 2009; Zhu and Demirov, 2011]. For simplicity, we reference coarse, eddy-permitting, and eddyresolving simulations as having a horizontal grid size of $\geq 1^{\circ}, 1 / 3-1 / 6^{\circ}$, and $\leq 1 / 10^{\circ}$, respectively. Using results from $1 / 12^{\circ}$ and $1 / 3^{\circ}$ ocean general circulation models (OGCMs), Böning et al. [2006] suggest that a mid-1990's decline in the SPNA circulation, associated with the AMOC, is part of a decadal variability pattern. This decadal pattern, based on the $1 / 3^{\circ}$ model, is superimposed on a trend of transport increase since about 1970 . Because horizontal resolution plays a critical role in simulating the narrow boundary current, which carries most of the transport in the western SPNA [Treguier et al., 2005], it is difficult to directly compare the model results from eddy-permitting or coarser resolution to observations. The purpose of this study is to examine the AMOC associated transports in the western SPNA, including both temporal variability and time-mean structure, using results from an eddy-resolving simulation and model-data comparisons. The results suggest that interannual and longer time scale variabilities are present but do not dominate the transport in the western SPNA. These comparisons yield general agreement between key model results and data.

[6] The paper is organized as follows: After the introduction, primary observational results on the transports of the western boundary current and trans-basin AMOC in the SPNA are briefly summarized in section 2 The numerical simulations used are described in section 3 In section 4, model transports associated with the AMOC in the SPNA are discussed in comparison with the observations. In section 5, we examine, on an approximately decadal time scale, the covariance of the boundary current and the AMOC transports in the context of the North Atlantic Oscillation (NAO [Hurrell, 1995]). Summary and discussion of the main results follow in section 6 . 


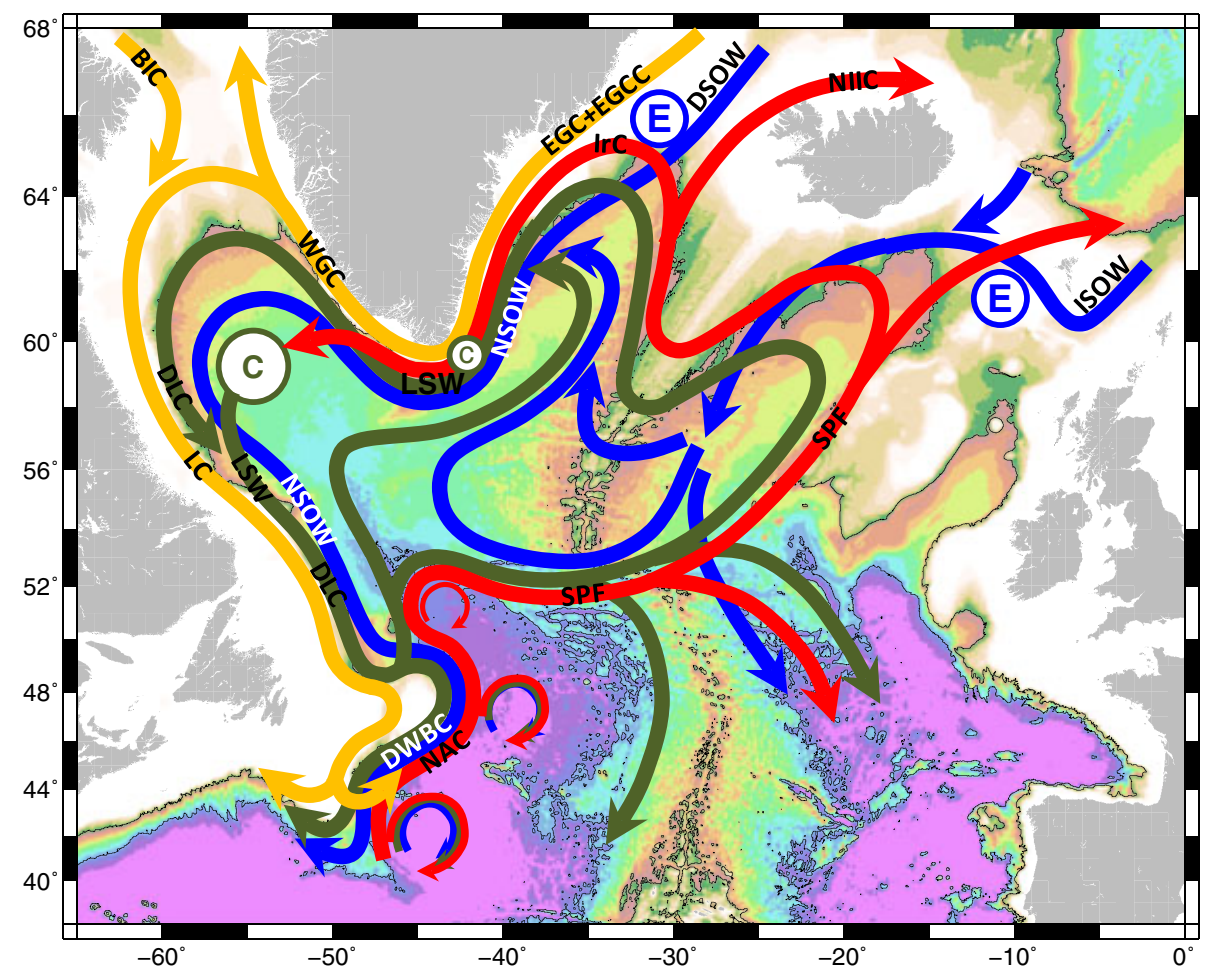

Figure 2. A data-based, three-layer schematic depiction of the circulation pattern in the subpolar North Atlantic. Red and deep yellow arrows represent the upper layer flow. Green and blue arrows represent the intermediate and deep layer circulations, respectively. ${ }^{\prime \prime} \mathrm{C}$ " denotes deep convection, and " $\mathrm{E}$ " entrainment. The current/water mass abbreviations are NAC: North Atlantic Current, SPF: Subpolar Front, IrC: Irminger Current, NIIC: North Icelandic Irminger Current, EGC: East Greenland Current, EGCC: East Greenland Coastal Current, WGC: West Greenland Current, BIC: Baffin Island Current, LC: Labrador Current, DLC: Deep Labrador Current, DWBC: Deep Western Boundary Current, LSW: Labrador Sea Water, DSOW: Denmark Strait Overflow Water, ISOW: Iceland-Scotland Overflow Water, NSOW: Nordic Seas Overflow Water.

\section{Transport From Observations}

[7] The reader is referred to Schott and Brandt [2007] for a review of the observational base related to the general circulation pattern connected with the AMOC in the SPNA (Figure 2). In this section, we focus on the key transport measurements that are relevant to this study, particularly, the boundary currents measured using moored current meter arrays near $53^{\circ} \mathrm{N}$ and $43^{\circ} \mathrm{N}$ (red circles in Figure 1), along with trans-basin AMOC transport estimates in this region.

[8] Since summer 1997, moored observations have been collected over varying time intervals and locations at the exit of the Labrador Sea near $53^{\circ} \mathrm{N}$ [Fischer et al., 2004, 2010]. For the first two years, this array consisted of five moorings covering the boundary current near the shelf break out into the deep Labrador Sea. Using these data, Fischer et al. [2004] estimated a 2 year mean, full-depth boundary transport of $37.2 \mathrm{~Sv}$ and an annual mean DWBC (below $\sigma_{\theta}$ $27.74 \mathrm{~kg} \mathrm{~m}^{-3}$ ) transport of $28.3 \mathrm{~Sv}$ in 1997 and $24.2 \mathrm{~Sv}$ in 1998. Due to various constraints, the array consisted of three moorings in 1999-2003, one (K9, at $2870 \mathrm{~m}$ water depth) in 2003-2007, back to three in 2007-2009, and five in 2009 2011. Comparison of the well-sampled Denmark Strait overflow water (DSOW) transport for 1997-1999 and 2009-2010 shows very similar means and variabilities (transport estimates for the full water column during 2009-2011 are not yet available). The velocity records collected at $\mathrm{K} 9$ provide a long-term view of how the boundary current has varied. Figure 3a, updated from Fischer et al. [2010], illustrates the time series of the alongshore flow ( $155^{\circ}$ from true north) at K9 during 1997-2010. The four selected depth levels represent the upper layer $(200 \mathrm{~m})$, LSW $(1500 \mathrm{~m})$, IcelandScotland overflow water (ISOW, $2400 \mathrm{~m}$ ), and DSOW $(2800 \mathrm{~m})$, respectively. Currents at all levels exhibit strong intraseasonal and shorter time scale variability. Fischer et al. [2010] calculated the spectra of the variability for each 2 year long segment of the records and found that there is a spectral peak at periods around 10-20 days and a rapid decay toward longer and shorter periods.

[9] Fischer et al. [2010] also found that the annual mean flow at all depths varies on the order of 10 percent relative to the "decadal" mean and that there are no detectable systematic trends in the boundary current intensity. In Figure 3b, the maximum and minimum (range) of the running-averaged alongshore velocity at $\mathrm{K} 9$ is plotted as a function of the averaging time scale. The current is characterized by high variability on short-time scales (less than a year) and rapidly decreasing variability toward longer time scales, e.g., with a range of $\sim 20 \mathrm{~cm} \mathrm{~s}^{-1}$ for the monthly averaged velocities and only $2-4 \mathrm{~cm} \mathrm{~s}^{-1}$ for 3 year averages. The latter range value is also significantly lower than the full-record mean velocity: 12.2, $12.7,18.9$, and $26.0 \mathrm{~cm} \mathrm{~s}^{-1}$ for upper layer, LSW, ISOW, 


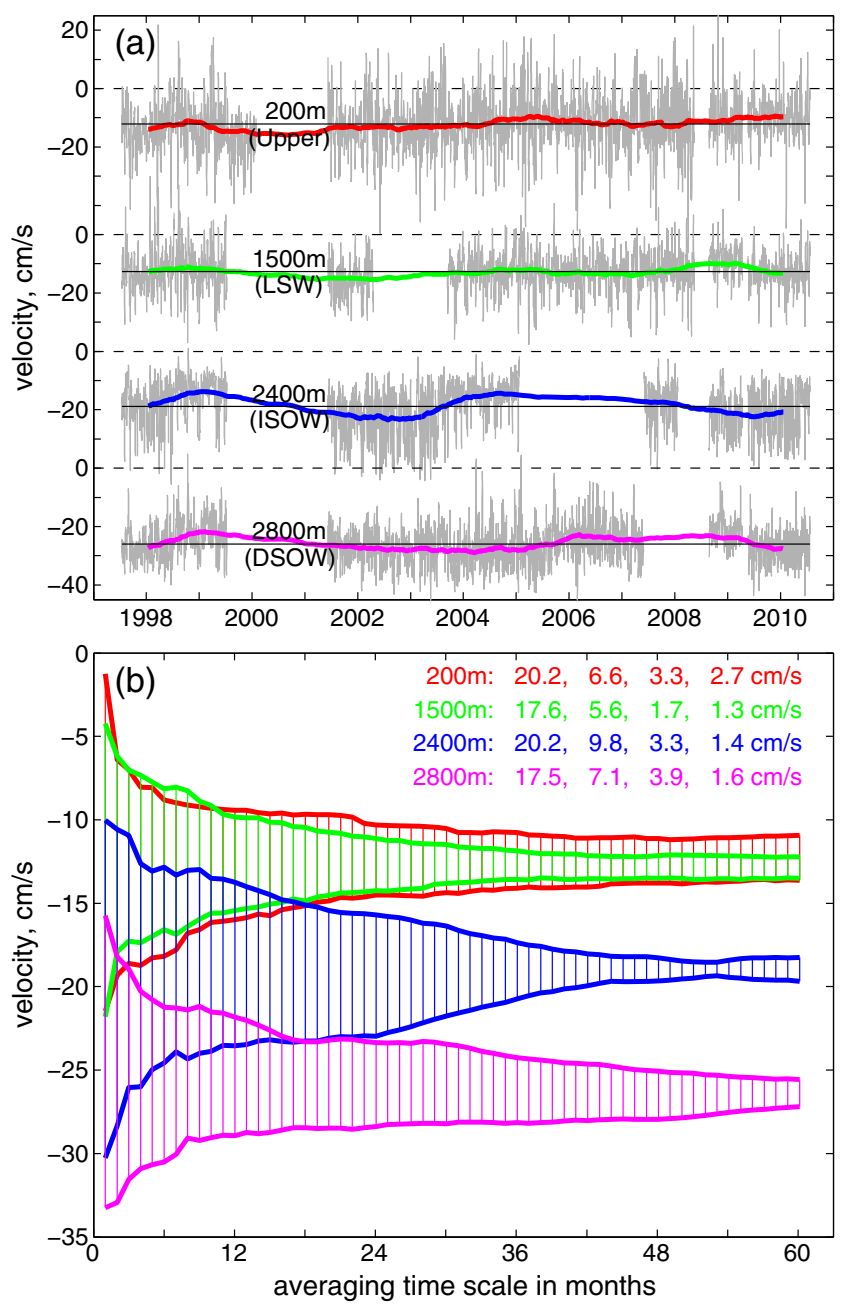

Figure 3. (a) Time series of the alongshore velocity at four selected depth levels from mooring K9 near $53^{\circ} \mathrm{N}$; similar to Figure 3a of Fischer et al. [2010], but including data from a recent deployment (May 2009-July 2010) and ADCP data at $200 \mathrm{~m}$ from the first three deployments (July 1997-January 2000). Thin gray lines denote velocities at $12 \mathrm{~h}$ resolution, and thick-colored lines denote 1 year averages. Horizontal black lines denote full-record means of 12.2, 12.7, 18.9, and $26.0 \mathrm{~cm} \mathrm{~s}^{-1}$ at 200, 1500, 2400, and $2800 \mathrm{~m} \mathrm{depth,}$ respectively. (b) Range of the averaged velocities as a function of averaging time scale. The color-coded numbers are the velocity ranges for $1,12,36$, and 60 month averages at each depth level. Note the record lengths vary between about 8 years $(2400 \mathrm{~m})$ and 11 years $(200 \mathrm{~m})$.

and DSOW, respectively. These results imply that longer-term variability does not dominate the observed mean current.

[10] Similar results were found east of the Grand Banks near $43^{\circ} \mathrm{N}$, where two sets of moored current meter records, each about two years long, were collected. The first set from 1993 to 1995 consisted of eight moorings, spanning about $500 \mathrm{~km}$ and laterally covering both the DWBC and part of the NAC [Clarke et al., 1998]. The second from 1999 to 2001 consisted of four moorings focusing on the DWBC near the continental slope. Based on these data, Schott et al. [2004] found that the DWBC transport is about the same over 1993-1995 and 1999-2001 (their Table 4). Furthermore, one mooring
(K104) was deployed for another four years (2001-2005), and the combined velocity records from this mooring (about 8 years) suggest a "surprisingly stable" boundary current when the approximately 2 year long means of each deployment are compared; see Schott et al. [2006] for details.

[11] Estimates of trans-basin AMOC transport in the SPNA have been derived primarily from repeated hydrographic sections. Results from three such sections yield very consistent mean AMOC transports: 16.2 Sv across the AR19 section [Lumpkin et al., 2008], 16.3 Sv across the A25 - Ovide section which runs southeastward from Cape Farewell to the Portuguese shelf [Lherminier et al., 2010], and 16.5 Sv across $59.5^{\circ} \mathrm{N}$ from Cape Farewell to Scotland [Sarafanov et al., 2012]. These AMOC transport estimates are also in rough agreement with the NADW formation rates calculated from chlorofluorocarbon inventories in the North Atlantic Ocean: $17.2 \pm 5.1 \mathrm{~Sv}$ in Smethie and Fine [2001] and $19.6 \pm 3.4$ $\mathrm{Sv}$ in LeBel et al. [2008]. From satellite observations of SSH along with temperature, salinity, and velocity from profiling floats, Willis [2010] estimated a mean AMOC transport of $15.5 \pm 2.4 \mathrm{~Sv}$ across $41^{\circ} \mathrm{N}$ in 2004-2006. He also suggested that despite significant seasonal to intraseasonal fluctuations, substantial slowing of the AMOC did not occur between 2002 and 2009, and is unlikely to have occurred in the past two decades.

\section{Eddy-Resolving Atlantic Simulations}

[12] Existing direct measurements in general are neither widely available nor long enough for discussion of long-term variability. In this study, we consider transport results determined from interannually forced, eddy-resolving simulations of the Hybrid Coordinate Ocean Model (HYCOM), using observations as a guide. Xu et al. [2010, 2012] have shown that the model results are helpful in addressing questions related to the time-mean transports of NSOW in the northern SPNA and to the AMOC structure in the subtropical North Atlantic near $26.5^{\circ} \mathrm{N}$. Here we consider the full water column transports in the SPNA, with emphasis on temporal variability.

[13] The OGCM simulations used for this study are similar to those described in Xu et al. [2012]. These simulations have a horizontal resolution of $0.08^{\circ}(\sim 6 \mathrm{~km}$ in the SPNA) and 32 layers in the vertical. The computational domain extends meridionally from $28^{\circ} \mathrm{S}$ to the Fram Strait at $80^{\circ} \mathrm{N}$. No inflow/outflow is prescribed at the northern and southern boundaries. Within a buffer zone of $3^{\circ}$ from the northern and southern boundaries, the model potential temperature $(\mathrm{T})$ and salinity (S) are restored to a monthly ocean climatology, the Generalized Digital Environmental Model (GDEM [Carnes, 2009]), with an $e$-folding time of 5-60 days that increases with distance from the boundary. Surface heat flux is given by

$$
H_{\text {net }}=H_{\text {shortwave }}+H_{\text {longwave }}+H_{\text {latent }}+H_{\text {sensible }},
$$

in which the surface short-wave radiation is from atmospheric reanalysis or prediction products (see below), the long-wave radiation, latent and sensible heat fluxes are calculated using the modeled sea surface temperature (SST) and the bulk formulae of Kara et al. [2005]. The latter provide negative feedback that increases/decreases the net heat flux if model $\mathrm{SST}$ is too cold/warm, and thus no SST restoring is applied 
in simulations discussed in this study.Surface freshwater flux is treated as a virtual salinity flux $\mathrm{F}_{\text {saln }}$

$$
\mathrm{F}_{\text {saln }}=(\mathrm{E}-\mathrm{P}-\mathrm{R}) \times \mathrm{SSS}-\mathrm{V} \times\left(\mathrm{SSS}-\mathrm{S}_{\text {clim }}\right),
$$

in which $\mathrm{E}, \mathrm{P}$, and $\mathrm{R}$ represent evaporation, precipitation, and river runoffs and the sea surface salinity (SSS) is restored to the GDEM climatology with a restoring strength $\mathrm{V}$ of $15 \mathrm{~m} / 30$ days. The value (of V) used is similar to other state-of-art models of comparable horizontal resolution in the SPNA region (e.g., $10 \mathrm{~m} / 15$ days in Brandt et al. [2007], $12 \mathrm{~m} / 12$ days in Chanut et al. [2008]). Previously in model simulation E026 [Xu et al., 2012], the salinity difference between model and climatology $\left(\mathrm{SSS}-\mathrm{S}_{\text {clim }}\right)$ was clipped to be no larger than 0.5 . Since the idea of reducing salinity restoring is to diminish its damping effect on ocean fronts, in the simulations discussed here, the clip is not applied in areas of low salinity $\left(\mathrm{S}_{\text {clim }}<34.5\right)$ and high salinity $\left(\mathrm{S}_{\text {clim }}>36.8\right)$. This small modification helps constrain the model salinization or salinity drift in the Labrador Sea, as discussed below.

[14] The other difference is that the simulation considered in this study was integrated much longer and used interannual rather than climatological forcing. Two simulations were performed. The climatological spin-up, E046, is a twin experiment of E026, but with the modified surface salinity restoring. The interannual experiment, E127, was initialized from E046 at the beginning of model year 11 and was integrated using two forcing products covering a time period of 1978-2011. The European Center for MediumRange Weather Forecasts 6 hourly, $1.125^{\circ}$ reanalysis (ERA40 [Uppala et al., 2005]) was used for 1978-2002 and the Fleet Numerical Meteorology and Oceanography Center 3 hourly, $0.5^{\circ}$ Navy Operational Global Atmospheric Prediction System (NOGAPS [Rosmond et al., 2002]) for 2002-2011. In the process, the long-term NOGAPS mean was replaced by the long-term mean from ERA40 to avoid new spin-up/down. In this study, we will primarily focus on the results from E127.

[15] Maintaining the $\mathrm{T} / \mathrm{S}$ properties is a well-known challenge for SPNA models. Specifically, OGCMs in this region, even with surface salinity restoring, typically suffer from model salinization in the Labrador Sea [Treguier et al., 2005; Brandt et al., 2007; Chanut et al., 2008; Rattan et al., 2010]. Spatially averaged $\mathrm{T}$ and $\mathrm{S}$ along hydrographic section AR7W (see Figure 1) are shown in Figure 4 to document the model drifts. The results of E026 in Figure 4 show two phases of salinization, similar to Rattan et al. [2010]. Fast salinization, accompanied by warming (Figure $4 \mathrm{a}$ ), in the first $4-5$ years is associated with the model adjustment away from its initial condition. This adjustment is followed by an extended, but slower drift of about 0.02 per decade. The latter drift rate is comparable to other OGCM simulations, e.g., about 0.04 per decade in Chanut et al. [2008]. The modification of surface salinity restoring reduced the salinity drift substantially, as shown by the difference between E026 and E046 in Figure 4b.

[16] Observational T/S based on high-resolution conductivity-temperature-depth data are included in Figure 4 to evaluate the variations in the model water properties (note
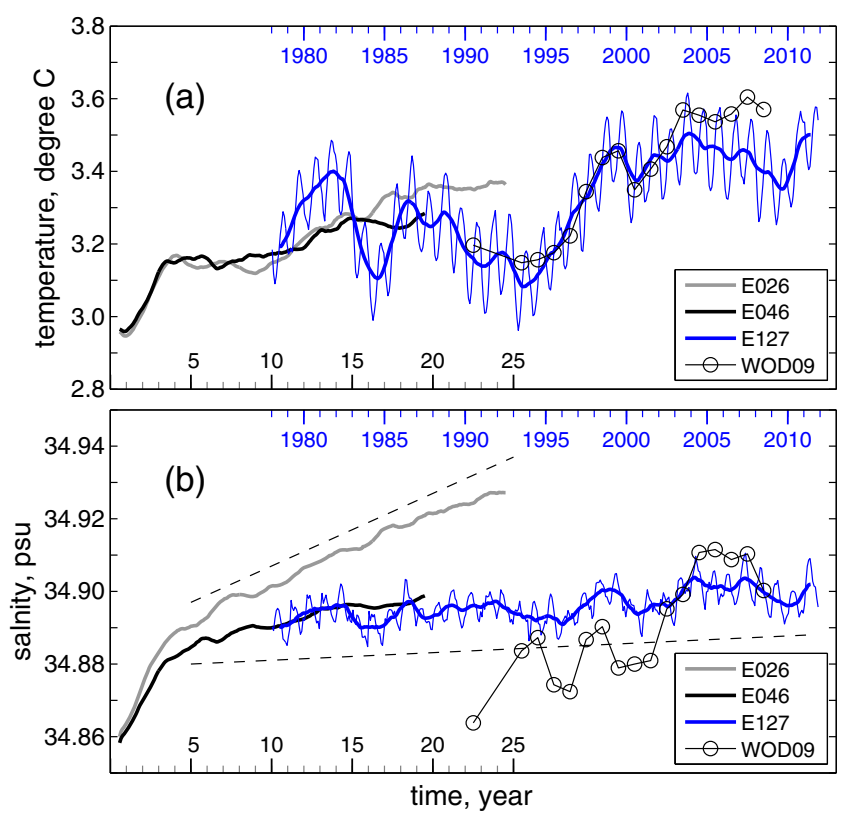

Figure 4. Spatially averaged (a) potential temperature and (b) salinity along the AR7W section as a function of time. Hydrographic data along this section, repeated almost annually since 1990, are available from the World Ocean Database 2009 (WOD09). The data-based T/S values (connected circles) are shifted by $0.5^{\circ} \mathrm{C} / 0.05$ for a better illustration of the model-data comparison. Results from climatological simulation E026 have been discussed in Xu et al. [2012]. Results of simulations E046 (climatological) and E127 (interannual) are discussed in this study. Thin lines denote monthly mean results (not shown for simulations E026 and 046), and the thick lines represent 12 month running averages. The two dashed lines in Figure $4 \mathrm{~b}$ indicate linear salinization of 0.02 in a decade and in a century. Blue year labels denote 1 January of the calendar year.

the observational $\mathrm{T}$ and $\mathrm{S}$ values are shifted by $0.50^{\circ} \mathrm{C}$ and 0.05 , respectively, for a better illustration of the variability comparison). The hydrographic surveys were carried out during May-July almost annually since 1990 by the Ocean Sciences Division at the Bedford Institute of Oceanography, Canada. Data from 1990 to 2008 were available in the World Ocean Database 2009. The T variation in simulation E127 is consistent with observations (Figure 4a). The details of the observed $\mathrm{S}$ variation are more difficult to interpret, but they generally show an increasing trend, consistent with other observations in the SPNA and Nordic Seas [Hátún et al., 2005; Sarafanov et al., 2008; Holliday et al., 2008]. The S in E127 exhibits a small drift (with a linear increase rate of 0.02 per century). Interannual variation in the model is significantly lower than observed. These results suggest that SSS restoring toward ocean climatology, a widely used practice to prevent/reduce model salinization in OGCMs, may have the undesirable effect of damping the natural salinity variation. Note that the small variation in model salinity could also be attributed to inadequate freshwater forcing, i.e., from the closed northern boundary and/or lack of a realistic ice model, etc. Overall, in the model results discussed in this study, variation in $\mathrm{T}$ is significantly higher (than in S) and dominates the density variation. 


\section{Model-Based Transports in the SPNA in Comparison With Data}

[17] In this section, we consider results from the interannually forced, eddy-resolving simulation E127, as described in section 3 . The eddy-resolving numerical model results have essentially no spatial/temporal sampling limitations. However, it is essential to determine whether the model results in the SPNA are consistent with observations, including their variability. Particular attention is devoted to model versus observed water property variations, western boundary current structure and variability, and to trans-basin AMOC transports. In the following subsections, we will examine the variation of water properties and associated SSH in the western SPNA (4.1), the western boundary current at the exit of the Labrador Sea (4.2) and east of the Grand Banks (4.3), and the AMOC transport across the hydrographic section AR19 (4.4).

\subsection{Temperature and SSH Variations in the Western SPNA}

[18] The spatially averaged $\mathrm{T}$ and $\mathrm{S}$ across the Labrador Sea have been shown in Figure 4. Figure 5 is the vertical distribution of the model average $\mathrm{T}$ of the boundary current across the $53^{\circ} \mathrm{N}$ mooring array in comparison with the winter time NAO index (December through March). On interannual and longer time scales, the model results show two periods of cold boundary current during the mid-1980s and the early 1990s, both related to a high NAO. The extended period of extremely

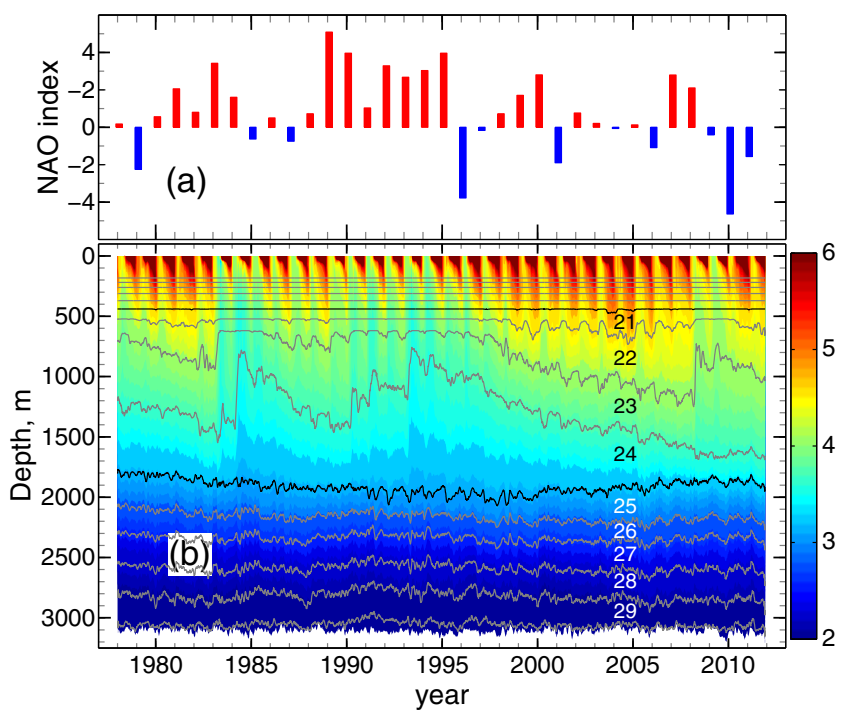

Figure 5. (a) Winter time (December through March) index of the North Atlantic Oscillation (NAO) during 1978-2011, based on the difference of normalized sea level pressure between Lisbon, Portugal and Reykjavik, Iceland [Hurrell, 1995]. (b) Potential temperature of the boundary current across the $53^{\circ} \mathrm{N}$ mooring array over $1978-2011$, based on a $0.08^{\circ}$ Hybrid Coordinate Ocean Model (HYCOM) simulation (E127). The model layer interfaces (not shown for the upper most 15 layers) are denoted in gray lines, with the upper interface of layers 21 and 25 highlighted in black. Layers 21-24 in model roughly represent Labrador Sea Water; layers 25 and below for Nordic Sea overflow water. Both temperature and interface are 1 month running averaged. The results could be compared to Figure 2b in Fischer et al. [2010]. high NAO (1989-1995) is well known. During this period, intense deep convection took place, and historically cold and fresh LSW was formed [Yashayaev, 2007]. Since about 1993-1994, the western SPNA has undergone a decade-long warming, which has been documented in several studies [e.g., Lazier et al., 2002; Yashayaev, 2007; Fischer et al., 2010]; see also Figure 4. The model-based warming in Figure 5 is highlighted by the deepening of the lower interface for model layers 22 and 23 , indicating that the warming signal penetrates well into the LSW layer. This result is consistent with the temperature record derived from mooring data over 1997-2009 at the same location [Fischer et al., 2010, their Figure 2b]. During the winter of $2007 / 8$ and 2008/9, the model results show a temperature drop. Cold temperature was observed during these two winters (especially 2007/8), associated with intense deep convection in the Labrador and Irminger Seas [Våge et al., 2009; Yashayaev and Loder, 2009; de Jong et al., 2012]. This temporary cold period may be a response to the relatively high NAO in 2007 and 2008 (Figure 5a).

[19] The change in temperature and thus heat storage is the key reason for SSH variation, although SSH toward high latitudes is also affected by an increasing salinity contribution to the density and by an increasingly barotropic flow structure. Satellite altimeter-based $\mathrm{SSH}$ is available for much of the global ocean since October 1992. The model-determined $\mathrm{SSH}$ variation in the central Labrador Sea is compared in Figure 6 with results from the weekly, $1 / 3^{\circ}$ gridded AVISO topography (http://www.aviso.oceanobs.com). Both model and observed SSH show a low-frequency increase since the mid-1990s, with some short-term variations superimposed. While a somewhat similar low-frequency variation has been shown in the eddy-resolving model results of Böning et al. [2006, their Figure 3a], the model variations of the monthly mean SSH are significantly more consistent with data in this study. The short-term variation is mainly due to the seasonal cycle of heating/cooling in the upper ocean (Figures 4 and 5). Spectral analysis suggests that both $\mathrm{SSH}$ and $\mathrm{T}$ time series have peak variability energy at the annual period (not shown here). The model SSH is low in the mid-1980s and early 1990 s corresponding to the period of cold boundary current. The rise of SSH since 1993, from which Häkkinen and Rhines [2004] inferred a significant decline in the SPNA circulation, is linked to the warming period. The temporary cold period during 2008-2009, however, is not clearly associated with a low in SSH, probably due to the effect of lower salinity (Figure 4).

\subsection{Boundary Current Across the $53^{\circ} \mathrm{N}$ Array}

[20] The model-based southeastward transport of the western boundary current across the $53^{\circ} \mathrm{N}$ mooring array is shown in Figure 7. The boundary transport is defined as the net flux across an area over which the time-mean velocity is southeastward. The 34 years of daily averaged transports have a mean of $39.0 \mathrm{~Sv}$ and a standard deviation of $7.9 \mathrm{~Sv}$. A majority of the variation is on intraseasonal and shorter time scales. Variability on interannual and longer time scales is significantly lower, with a standard deviation of $2.5 \mathrm{~Sv}(2.0 \mathrm{~Sv})$ for the annual (4 year) mean transports. There is no systematic trend over the 34 years of integration. The multiyear mean results clearly show a long-term variation of the boundary current from a time period of high transport in 1984-1997 to a period of low transport in 1997-2010. The difference in mean 


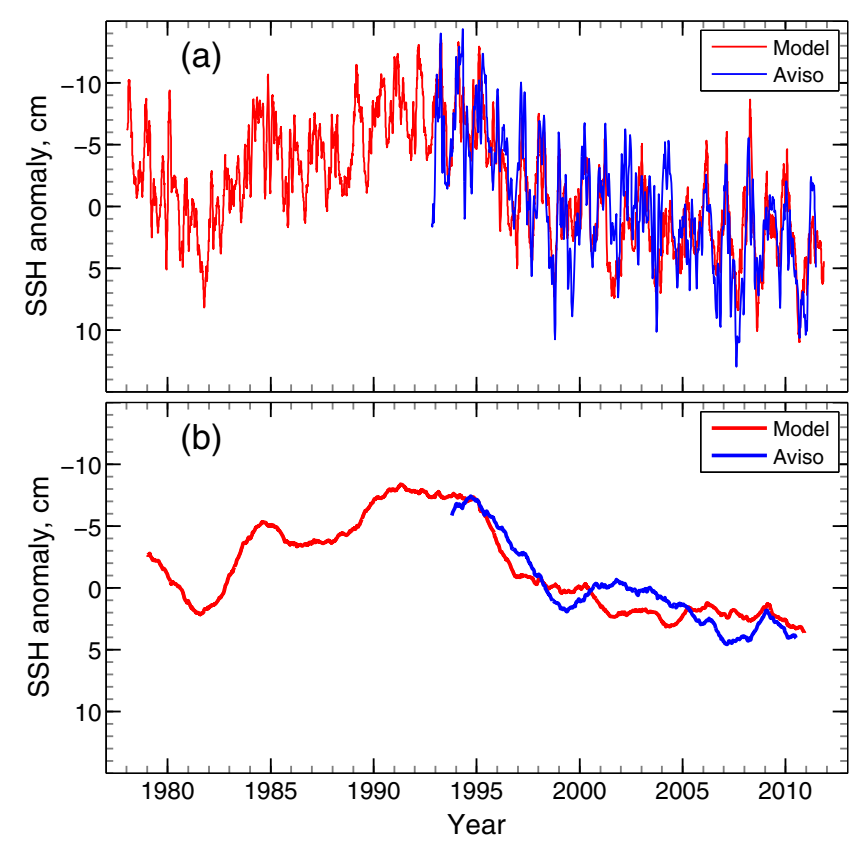

Figure 6. Variation of sea surface height (SSH, cm) anomaly in the central Labrador Sea $\left(57^{\circ} \mathrm{N}, 52^{\circ} \mathrm{W}\right)$ based on the $0.08^{\circ}$ HYCOM simulation E127 (red lines) and merged altimeter data (blue lines) from http://www.aviso.oceanobs.com. The data have a resolution of $1 / 3^{\circ}$, and the model results are averaged over a $1 / 3^{\circ}$ square. ( $a$ and $b$ ) 1 month and 2 year running averages, respectively. The results could be compared to Figure 3 a in Böning et al. [2006].

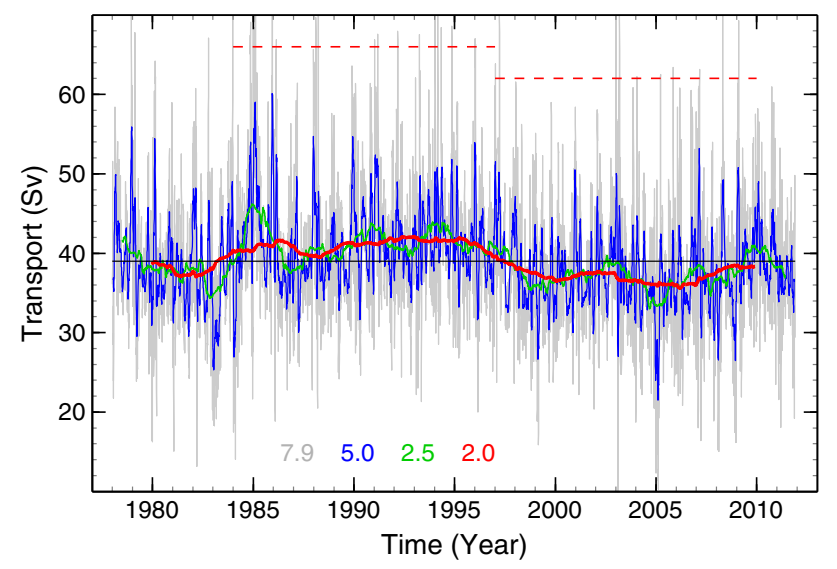

Figure 7. Model-based, boundary current transports across the moored array near $53^{\circ} \mathrm{N}$ for the time period $1978-2011$. The gray line denotes daily mean transports; blue, green, and red lines monthly, yearly, and 4 year running averages. The colored numbers are standard deviations for the corresponding time averages. The horizontal black line is the 34 year mean transport (39.0 Sv); two dashed red lines denote periods of high transport from 1984 to 1997 and low transport from 1997 to 2010).

transport between these two periods is $3.9 \mathrm{~Sv}, 10 \%$ of the long-term mean. These model results, consistent with the velocity measurements discussed in section 2 , suggest that long-term variability is present but does not dominate the mean boundary current transport in the western SPNA.

[21] To inspect the relationship between $\mathrm{SSH}$ in the central Labrador Sea and boundary transport at $53^{\circ} \mathrm{N}$, the two yearly running averages are plotted together in Figure 8. Similar to the results from eddy-permitting simulations [Böning et al., 2006; Zhu and Demirov, 2011], there is some correlation between low SSH and high boundary transports on a decadal time scale (see section 5 for more details). From 1994 to 1999 , the $\mathrm{SSH}$ rose about $8 \mathrm{~cm}$, and the boundary transport decreased about $7 \mathrm{~Sv}$. This transport decline is within the 7-10 Sv range estimated by Häkkinen and Rhines [2004]. The relationship between SSH and boundary current transport is not robust on interannual and shorter time scales, however. For example, the two yearly averaged time series in Figure 8 have a maximum cross-correlation coefficient of only 0.30 with SSH leading by 195 days (not shown). To explore the reason, the boundary transport is broken down into three layers in Figure 9, roughly representing an upper layer above $500 \mathrm{~m}$, a middle layer of LSW between 500 and 1900 $\mathrm{m}$, and a lower layer of NSOW below 1900 m; see Figure 5 for layer depth. The results suggest that the variation in boundary transport is primarily a contribution from the LSW layer and not from the upper layer. It should be pointed out that while there is large thickness variation within the LSW layer among model layers 22 to 24, similar to the observed thickness change between upper and classic LSW [Kieke et al., 2007], the variation of total LSW layer thickness is relatively small. Thus, the transport variation, as shown in Figure 9b, is primarily due to velocity change. The small transport variation of the lower layer (Figure 9c), on the other hand, is linked to the thickness change.

[22] The observed and modeled structures of the alongshore velocity are compared in Figure 10. The observed boundary current (Figure 10a) contains two cores of maximum velocity. One near the shelf break in the upper $500 \mathrm{~m}$ is associated with the Labrador Current (LC), and the other located at depths below $3000 \mathrm{~m}$ is associated with DSOW. A similar structure can be found in the boundary current derived from lowered acoustic Doppler current profilers (LADCPs), or from geostrophic currents referenced by mooring and float data [Fischer et al., 2004, 2010]. The model

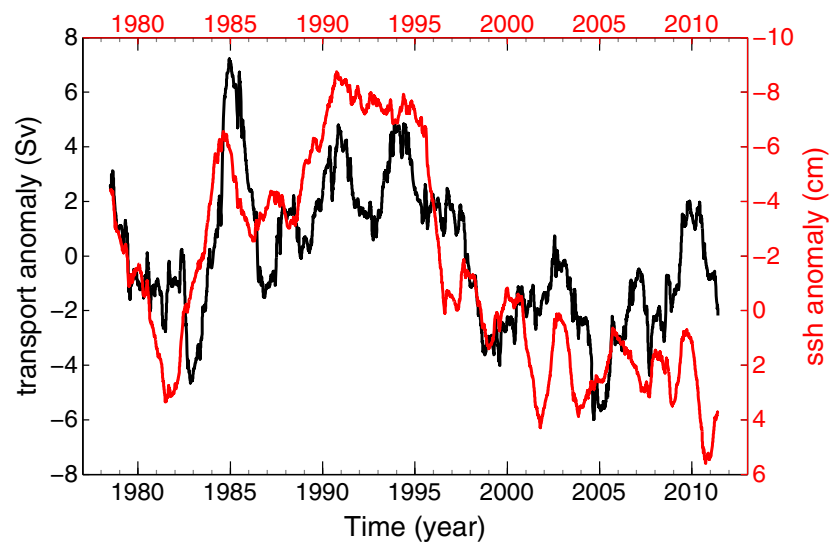

Figure 8. Variation of the model-determined boundary transport (in $\mathrm{Sv}$ ) across the $53^{\circ} \mathrm{N}$ mooring array (black line) and SSH $(\mathrm{cm})$ in the central Labrador Sea (red line), both as yearly running averages. 


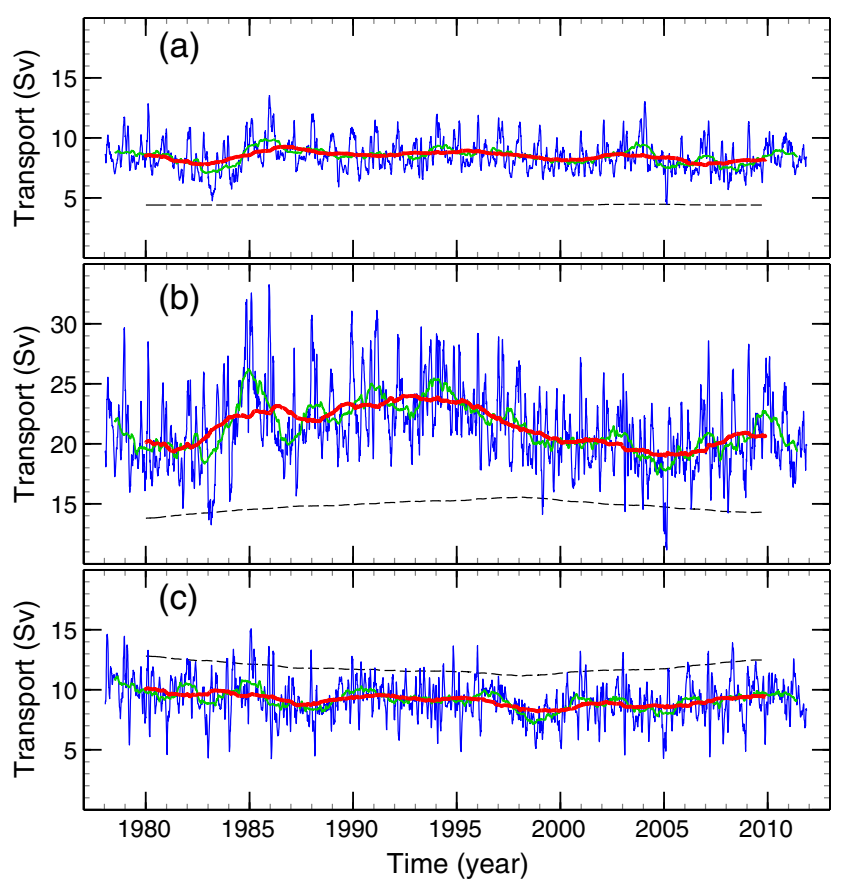

Figure 9. Modeled boundary current transports across the moored array near $53^{\circ} \mathrm{N}$ broken down into three layers: (a) model layer 1-20 $\left(\boldsymbol{\sigma}_{\mathbf{2}} \leq 36.62 \mathrm{~kg} \mathrm{~m}^{-3}\right)$, (b) model layer 21-24 (36.70 $\left.\leq \boldsymbol{\sigma}_{\mathbf{2}} \leq 36.89\right)$, and (c) model layer 25 and below $\left(\boldsymbol{\sigma}_{\mathbf{2}} \geq 36.97\right)$. Blue, green, and red lines in each panel denote monthly, yearly, and 4 year running averages, respectively. Dashed lines denote thickness (in hundred meters) of each layer.

results yield a well-defined boundary current with a slanting offshore structure similar to observations (Figure 10b). There are several key differences, however. Vertically, the baroclinic signatures of both LC and DSOW are missing. The latter is highlighted best by the discrepancy in the velocity profile at mooring K9 near the bottom (Figure 10c). The model-based maximum velocity is about $17 \mathrm{~cm} \mathrm{~s}^{-1}$ (versus $26 \mathrm{~cm} \mathrm{~s}^{-1}$ observed). Horizontally, the model-based boundary current is slightly narrower and is located more inshore than observed. As a result, the current at K8 is significantly stronger than observed.

[23] Consistent time-mean volume transports of the boundary current near $53^{\circ} \mathrm{N}$ have been estimated from moored current meter data, repeat LADCP surveys, and geostrophic currents referenced to measured velocities (Table 1). The model-based mean transport of $39.0 \mathrm{~Sv}$ is also in good agreement. The model results yield a similar depth for isopycnal $\left(\sigma_{\theta}\right.$, in $\left.\mathrm{kg} \mathrm{m}^{-3}\right)$ of 27.80, a typical interface for separating LSW and NSOW. The model-based transport below this isopycnal is lower than observed (10 Sv versus $14 \mathrm{~Sv})$ and higher above this isopycnal. Transports of different water masses above and below 27.80 are sensitive to the density structure. For example, the model-based isopycnal of 27.88 (between ISOW and DSOW in this area) is significantly shallower than observed. As a consequence, the modeled transport of DSOW is comparable to observations, even though the maximum velocity is not well represented. On the other hand, isopycnal 27.74 between upper (uLSW) and classical LSW (cLSW) is deeper in the model than observed, which results in a slightly lower cLSW transport. It should be noted that the density structure above 27.80 varies among the model simulations. For example, due to higher salinity, the 27.74 isopycnal from simulation E026 in Xu et al. [2012] is about $300 \mathrm{~m}$ deep (too shallow) in the boundary current, leading to a much stronger transport in cLSW (Table 1).

\subsection{Western Boundary Current Near $43^{\circ} \mathrm{N}$}

[24] Part of the western boundary current observed at the exit of the Labrador Sea flows eastward through the CharlieGibbs Fracture Zone (see Figure 2). The remainder continues to flow southward around the Flemish Cap and the Grand Banks before entering the subtropical North Atlantic. The transport of the modeled southwestward boundary current (a)

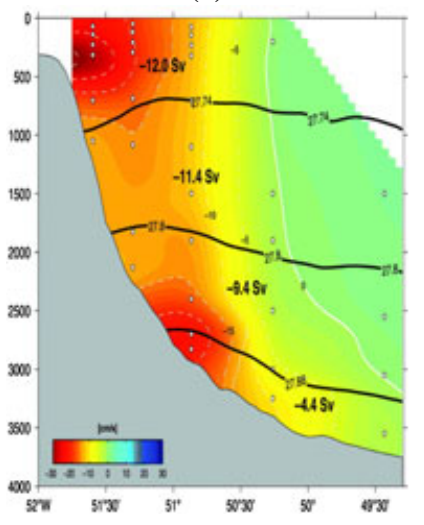

(b)

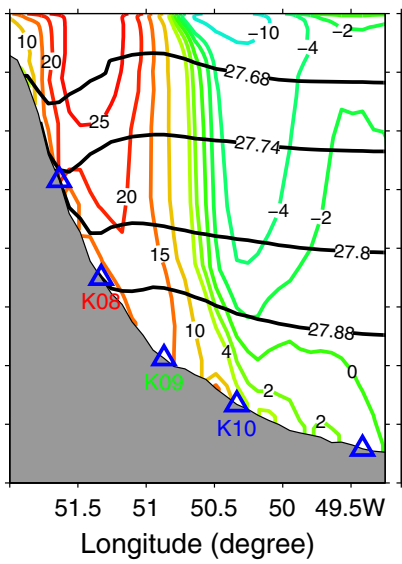

(c)

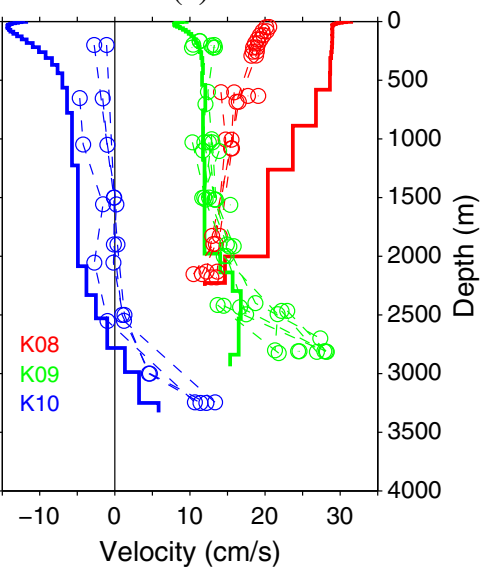

Figure 10. (a) Observed and (b) modeled time-mean alongshore velocity (in $\mathrm{cm} \mathrm{s}^{-1}$ ) across the mooring array at the exit of the Labrador Sea near $53^{\circ} \mathrm{N}$. Observation results are reproduced from Figure 11 in Fischer et al. [2004]. Model results are based on simulation E127, averaged over the same time period, namely August 1997 to July 1999. (c) Comparison of velocity profiles at mooring locations K8 (red), K9 (green), and K10 (blue). The dashed lines with circles denote annual mean profiles from all the moored current meter records; thick solid lines are model results. 
Table 1. Mean Transport of the Western Boundary Current at the Exit of the Labrador Sea Near $53^{\circ} \mathrm{N}^{\mathrm{a}}$

\begin{tabular}{|c|c|c|c|c|c|c|}
\hline Water Mass & Mooring & Geostrophy & LADCP & E127 & E046 & E026 \\
\hline Upper layer $(<27.68)$ & 12.0 & 13.5 & -6.3 & $\begin{array}{r}-4.5 \\
-15.5\end{array}$ & $\begin{array}{r}-2.7 \\
-15.4\end{array}$ & -1.5 \\
\hline cLSW (27.74-27.80) & -11.4 & -11.4 & -11.3 & -8.8 & -11.4 & -23.2 \\
\hline ISOW (27.80-27.88) & -9.4 & -8.4 & -10.5 & -5.2 & -5.2 & -6.7 \\
\hline DSOW $(\geq 27.88)$ & -4.4 & -3.4 & -4.8 & -5.0 & -5.0 & -5.1 \\
\hline Full water column & -37.2 & -36.7 & -41.8 & -39.0 & -39.7 & -40.9 \\
\hline
\end{tabular}

${ }^{\mathrm{a}}$ Units are in Sv, negative southeastward. The transports based on moored current meter array and geostrophy are from Fischer et al. [2004], in which one transport value is given for water above $\left(\sigma_{\theta}\right) 27.74 \mathrm{~kg} \mathrm{~m}^{-3}$. The mooring array covers a time period of July 1997-July 1999. Geostrophic results are based on hydrographic surveys during 1996-2001, with reference velocity from mooring and float data. The LADCP results are based on nine sections during 1996-2009 [Fischer et al., 2010]. The model results are based on a 34 year mean for interannual simulation E127 (years 1978-2011) and a 5 year mean for climatological simulations E046 and E026 (years 16-20). Results from E026 were discussed in Xu et al. [2012].

across the mooring array near $43^{\circ} \mathrm{N}$ is shown in Figure 11. This boundary transport, similar to Figure 7, is defined as the net flux across an area over which the time-mean velocity is southwestward. The boundary current at $43^{\circ} \mathrm{N}$ exhibits no trend, similar to that at $53^{\circ} \mathrm{N}$. The 34 year mean transport is 15.9 Sv, but the transport variability is high. The daily and monthly mean transports have standard deviations of 11.6 and $9.8 \mathrm{~Sv}$. The interannual and longer time scale variabilities are significantly lower relative to short-term variability (but higher than at $53^{\circ} \mathrm{N}$ ). The 4 year running mean transports in Figure 11 clearly show variation on a decadal time scale, with high transports in the late 1990s and low transports in the mid-1980s and late 2000s. This result appears to be in conflict with the "surprisingly stable" boundary current depicted in Schott et al. [2006]. However, their measurements (1993-1995 and 1999-2005) did not cover the time periods of high or low transports. For the four approximately 2 year periods considered in Schott et al. [2006], the model results yield mean transports with a narrow range of values, $14.9,14.4,15.2$, and $15.0 \mathrm{~Sv}$.

[25] The model-based time-mean boundary current across the mooring array near $43^{\circ} \mathrm{N}$ is compared with observations in Figure 12. The model results, averaged over August 1993-July 1995 and July 1999-May 2001 (the mooring periods), yield an approximately consistent flow structure

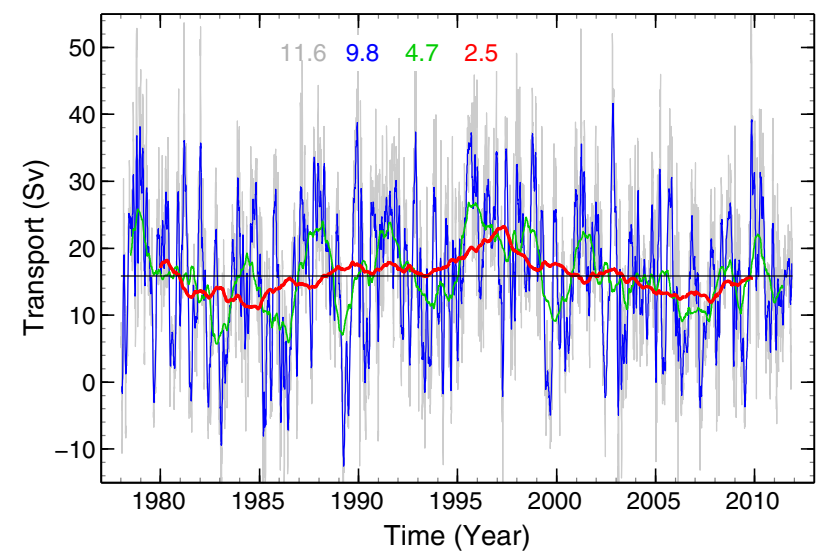

Figure 11. Transport of the boundary current across the moored array near $43^{\circ} \mathrm{N}$ from 1978 to 2011 based on simulation E127. The gray line denotes daily mean transports; blue, green, and red lines for monthly, yearly, and 4 year running averages, respectively. Colored numbers are standard deviations for the corresponding time averages. The horizontal black line is the 34 year mean transport (15.9 Sv). of the southward flowing DWBC and northward flowing NAC. Similar to observations, the modeled DWBC contains two high-velocity cores, associated with LSW (500-1500 m) and DSOW (below $3000 \mathrm{~m}$ ). While the overall velocity profile is in general agreement, the modeled flow magnitude of DSOW is weaker than observed, as highlighted near the bottom of mooring K104 (3.4 versus $8.7 \mathrm{~cm} \mathrm{~s}^{-1}$ ). On the other hand, the velocity for LSW is stronger in the model than in the observations, and the total DWBC transport is comparable between model and observations (see Table 2). Offshore of the DWBC, the observations yield a strong northward transport of $140 \mathrm{~Sv}$ for the NAC and recirculation. The model mean transport over the mooring periods is $74.5 \mathrm{~Sv}$ (about $60 \mathrm{~Sv}$ for 34 year mean). Similar transport values (46.9 - 71.0 Sv) are found in Table 2 of Bryan et al. [2007], using the $1 / 10^{\circ}$ Parallel Ocean Program. The large difference between model and observations is probably due mainly to the representation of the eddy-driven recirculation associated with the Mann eddy; see Meinen [2001] for some insightful discussion. This challenge may be related primarily to a more general difficulty in simulating the energetic eastern extension of the Gulf Stream in OGCMs [Hurlburt and Hogan, 2000, 2008; Hurlburt et al., 2011]. It is noteworthy that results from simulation E026 yield a stronger NAC, with a transport of $80 \mathrm{~Sv}$. This simulation, due to a larger contribution from LSW, also has a slightly higher AMOC transport (see below).

\subsection{AMOC Across the AR19 Section}

[26] The model-based, trans-basin AMOC transport across the hydrographic section AR19 and comparison to the boundary current transport near $53^{\circ} \mathrm{N}$ are shown in Figure 13. The AMOC transport is calculated as the net northward transport above a neutral density $\gamma^{n}$ of maximum overturning based on a time-mean profile (Figure 14). The model-determined mean AMOC transport is $16.4 \mathrm{~Sv}$ above $\gamma^{n}$ of $27.75 \mathrm{~kg} \mathrm{~m}^{-3}$, similar to the mean value $16.2 \mathrm{~Sv}$ above $\gamma^{n}$ of $27.81 \mathrm{~kg} \mathrm{~m}^{-3}$ from five hydrographic surveys [Lumpkin et al., 2008]. The modelbased mean AMOC transport, similar to the boundary current, exhibits no systematic trend over the 34 years of model integration and is dominated by high variability on intraseasonal and shorter time scales (Figure 13a). The monthly and daily mean transports have a standard deviation of 3.8 and $6.7 \mathrm{~Sv}$, respectively. The variability on interannual and longer time scales is significantly lower, with a standard deviation of 1.7 $\mathrm{Sv}$ for the annual mean transports. This value is also much lower than the $4.7 \mathrm{~Sv}$ for the corresponding annual mean transports of the western boundary current transports just east of the 
(a)

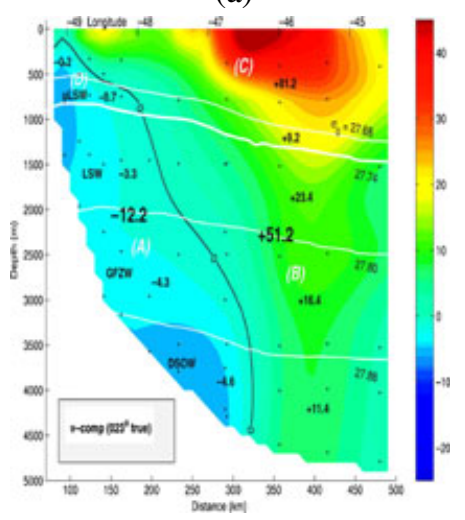

(b)

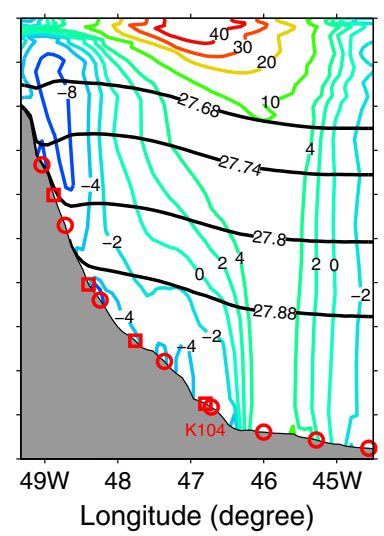

(c)

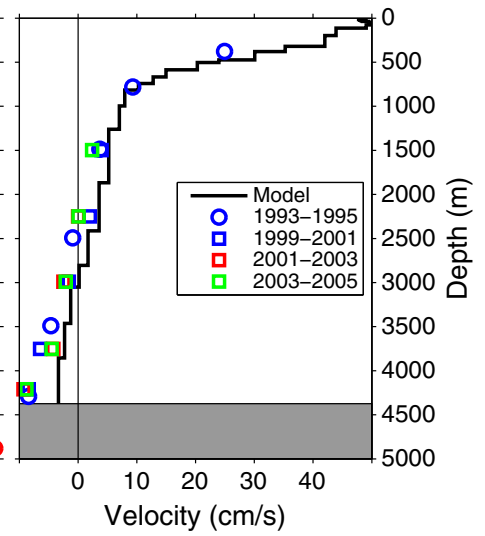

Figure 12. (a) Observation and (b) model-based mean alongshore velocity (in $\mathrm{cm} \mathrm{s}^{-1}$ ) across the mooring array east of the Grand Banks near $43^{\circ} \mathrm{N}$. Observation results are reproduced from Figure 8 in Schott et al. [2004]. Model results are based on simulation E127, averaged over roughly the same time periods of August 1993-June 1995 and August 1999-May 2011. (c) Comparison of velocity profiles at mooring location K104. The colored circles and squares are 2 year mean profiles from observations. The thick solid line is the model profile.

Table 2. Mean Transport of the Western Boundary Current East of the Grand Banks Near $43^{\circ} \mathrm{N}^{\mathrm{a}}$

\begin{tabular}{lrrrrr}
\hline Water Mass & LADCP & Mooring & E127 & E046 & E026 \\
\hline Upper layer $(<27.68)$ & -5.2 & -0.2 & -2.9 & -2.2 & -1.9 \\
uLSW (27.68-27.74) & -2.5 & -0.7 & -3.3 & -4.6 & -3.8 \\
cLSW (27.74-27.80) & -4.5 & -3.3 & -2.5 & -3.2 & -5.5 \\
ISOW (27.80-27.88) & -6.9 & -4.3 & -2.3 & -2.0 & -2.8 \\
DSOW ( $\geq 27.88)$ & -3.6 & -4.6 & -4.9 & -4.7 & -5.3 \\
DWBC ( $\geq 27.68)$ & -17.5 & -12.9 & -13.0 & -14.5 & -17.4 \\
\hline
\end{tabular}

${ }^{\mathrm{a}}$ Units are in Sv, negative southeastward. The mooring results are based on two arrays that cover a time period of 1993-1995 and 1999-2001 [Schott et al., 2004]. The LADCP results are based on four sections during 1999 to 2001 [Schott et al., 2006]. The model results are based on a 34 year mean for interannual simulation E127 (years 1978-2011) and a 5 year mean for climatological simulations E046 and E026 (years 16-20). Results from E026 were discussed in $X u$ et al. [2012].

Grand Banks. On a decadal time scale, the mean transport is high during about 1989-1999 and low during 1999-2010, with a mean transport difference of $2.9 \mathrm{~Sv}$. This decadal variation of the AMOC transport is positively correlated to the boundary transport near $53^{\circ} \mathrm{N}$ (Figure $13 \mathrm{~b}$ and section 5). Comparison of long-term mean results from simulations E127, E046, and E026 also indicates that experiments with a higher boundary current transport (Table 1) also have higher AMOC transport (Figure 14). This result is similar to Böning et al. [2006] and a majority of coupled climate models; e.g., Table 1 in Yoshimori et al. [2010]. However, Zhang [2008], also based on results of a coupled climate model, suggests that an increase in the SPNA circulation corresponds to a decrease in AMOC transport.

[27] It has been suggested in several papers that the DWBC does not account for all of the lower limb of the AMOC transport and that there exist interior pathways; see Bower et al. [2009] and Lozier [2010] for recent discussions. It is therefore of interest to examine the lateral structure of the transport across AR19. In Figure 15 the time-mean, full-depth transport accumulated eastward, based on simulations E026, E046, and
E127 as described in section 3, is compared to the inverse results of Lumpkin et al. [2008]. Results from these simulations show a very similar transport structure, with (1) the southward DWBC over the continental slope and (2) the northward flowing NAC and recirculation offshore in the deepest portion of the Newfoundland Basin (west of $\left.\sim 40^{\circ} \mathrm{W}\right)$. This transport pattern is approximately consistent with the inverse results, but with lower transport magnitude in the model. The model results also yield a similar net southward transport to the east of about $40^{\circ} \mathrm{W}$ as the inverse results. However, the southward transports take place primarily in the eastern basin in the model, whereas within the western basin in the inverse calculations (Figure 15).

[28] To further examine the details of the AMOC structure across the AR19 section, the cumulative transport is broken down into five density $\left(\sigma_{\theta}\right.$, in $\left.\mathrm{kg} \mathrm{m}^{-3}\right)$ layers, representing the modified North Atlantic Water $(<27.64)$, uLSW (27.64-27.74), cLSW (27.74-27.80), ISOW (27.80-27.88), and DSOW ( $>27.88$ ) (Figure 16). Note that the modelbased $\sigma_{\theta}$ of maximum overturning, used here for the upper interface of uLSW, is slightly lighter than the typical value of 27.68. For the northward limb of the AMOC (Figure 16a), the transport is mainly in the NAC and its recirculation and the net transport east of $\sim 40^{\circ} \mathrm{W}$ is close to zero. This result is expected since the majority of the AR19 section approximately follows a line of zero wind curl (thus weak Sverdrup transport). For the two LSW components (Figure 16b), the DWBC accounts for a southward transport of 5.2 and 2.4 Sv, compared to a net trans-basin transport of 5.0 and 4.1 $\mathrm{Sv}$. In both layers, southward transports are found in the eastern basin as well as over the western flank of the Mid-Atlantic Ridge (MAR). For ISOW and DSOW (Figure 16c), the DWBC accounts for 2.1 and $4.9 \mathrm{~Sv}$, compared to a trans-basin transport of 2.8 and $4.5 \mathrm{~Sv}$. Simply speaking, 14.6 out of the model-based 16.4 Sv mean AMOC transport at this latitude is carried southward via the DWBC. The rest, along with the return flow of the NAC, takes interior pathways and flows southward over the MAR and in the eastern basin. A westward DWBC is also clearly seen in the model section immediately 

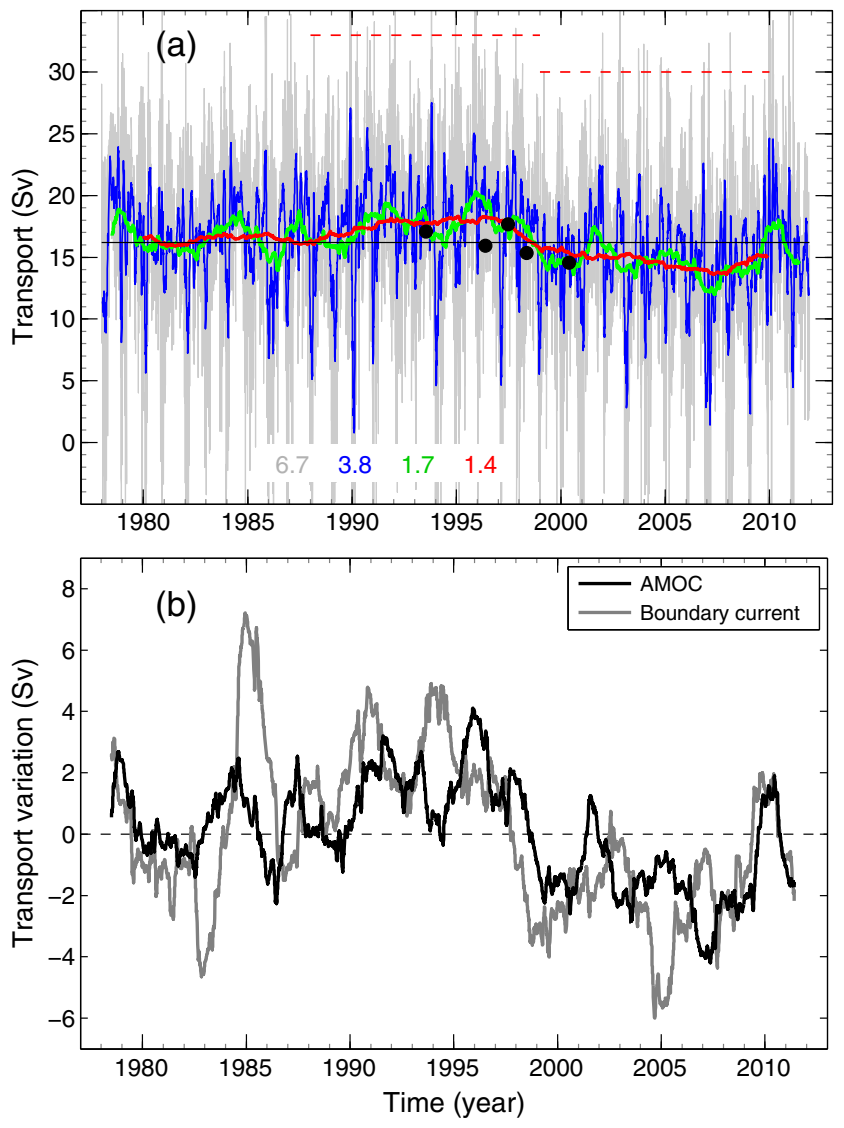

Figure 13. (a) Trans-basin AMOC transport across the hydrographic section AR19 based on simulation E127 for 1978-2011. The gray line denotes daily mean transports, the blue, green, and red lines monthly, yearly, and 4 year running averages. The colored numbers are standard deviation for corresponding averaged transports. The horizontal black line is the long-term mean transport (16.4 Sv). The five black dots denote the AMOC transports estimated from hydrographic data [Lumpkin et al., 2008]. (b) Variation of the model-based AMOC transport across the AR19 section (black) and boundary transport across the $53^{\circ} \mathrm{N}$ mooring array (gray), both in 1 year running averages.

west of the Grand Banks (along $50^{\circ} \mathrm{W}$, not shown), with a higher transport due to recirculation. It is also noteworthy that while the values are slightly different, the results from the three simulations yield a very similar general picture of the DWBC carrying most of the AMOC transport.

\section{Decadal Variation of the SPNA Transport}

[29] It is clear that all of the time series discussed in section 4, i.e., SSH (Figure 6), temperature (Figures 4a and 5), boundary transports (Figures 7, 8, and 11), and AMOC transport (Figure 13) exhibit some variations on an approximately decadal time scale, although masked by shorter term variability. A natural question would be if or how they are correlated, especially in the context of the NAO, the dominant climate variability mode in the North Atlantic region. This question is addressed here using a simple crosscorrelation analysis.

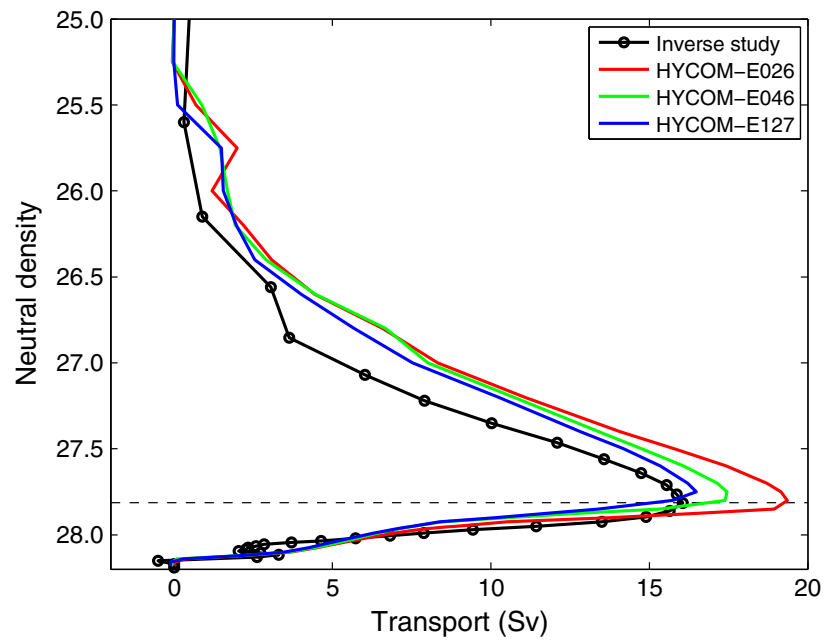

Figure 14. Time-mean, trans-basin net transports across the hydrographic section AR19, cumulative from surface to bottom as a function of neutral density $\left(\boldsymbol{\gamma}^{\boldsymbol{n}}\right.$, in $\left.\mathrm{kg} \mathrm{m}^{-3}\right)$. The inverse results are based on five hydrographic surveys during 1993-2000 [Lumpkin et al., 2008]. The horizontal dashed line $\left(\boldsymbol{\gamma}^{n}=27.81\right)$ denotes the density of maximum overturning transport based on inverse results. The model results are based on a 34 year mean for interannual simulation E127 (years 1978-2011) and 5 year means for climatological simulations E046 and E026 (years 16-20).

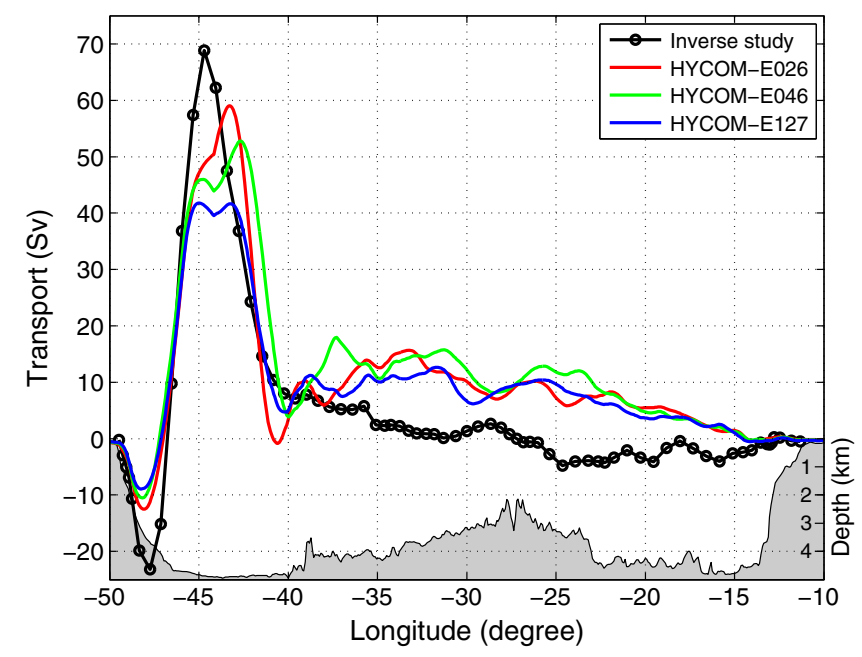

Figure 15. Time-mean, full water column transports across the hydrographic section AR19, cumulative eastward. The inverse results are based on five hydrographic surveys during 1993-2000 [Lumpkin et al., 2008]. The model results are based on a 34 year mean for interannual simulation E127 (years 1978-2011) and 5 year means for climatological simulations E046 and E026 (years 16-20).

[30] In Figure 17, the boundary current transport near $53^{\circ} \mathrm{N}$ is compared to (1) the observed winter time NAO index, (2) the model SSH in the central Labrador Sea and temperature across the boundary current at $53^{\circ} \mathrm{N}$, and (3) the model transports of the AMOC across the AR19 line and the boundary current at $43^{\circ} \mathrm{N}$. A 4 year running average is applied to filter out variabilities of interannual and shorter 


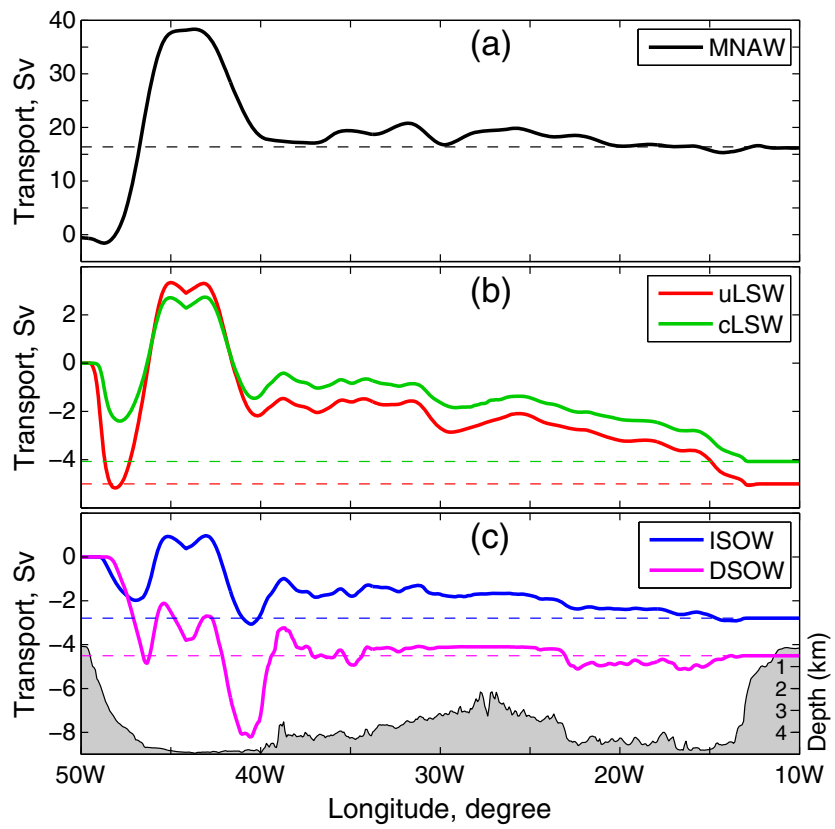

Figure 16. Time-mean meridional transports of different water masses across the hydrographic section AR19, cumulative eastward. The results are based on a 34 year mean from simulation E127 (years 1978-2011). The water masses are defined in potential density $\boldsymbol{\sigma}_{\boldsymbol{\theta}}$ ranges (in $\mathrm{kg} \mathrm{m}^{-3}$ ): modified North Atlantic Water $(<27.64)$, upper Labrador Sea Water (27.64-27.74), classical Labrador Sea Water (27.74-27.80), ISOW (27.80-27.88), and DSOW ( $\geq 27.88)$. Horizontal lines denote the trans-basin net transport for each density range.

time scales while keeping the record long enough to discuss decadal variability. In order to compare quantities of different dimension, each running-averaged time series is normalized by its range of variation. For a better illustration of the correlation, some time series in Figure 17 are shifted based on the time lag determined by cross-correlation (Figure 18). Several points can be made here. First, the boundary transport at $53^{\circ} \mathrm{N}$ is correlated with the observed NAO with a time lag of about 2 years (763 days, NAO leading). Note that the correlation coefficient $(0.45)$ is not significant on $95 \%$ level given the low degree of freedom, and a much longer simulation is required to evaluate the variations on decadal time scales and their correlations. Zhu and Demirov [2011] found that, in their $1 / 4^{\circ}$ simulation, the SPNA circulation in the 1980 s and 1990s closely follows the decadal NAO variations with a delay of about 3 years. On the other hand, Han et al. [2010] found a zero lag between the hydrographic data-based boundary transport and the NAO and suggested a fast oceanic response that is predominately barotropic in nature.

[31] Second, the SSH in the central Labrador Sea and the temperature and transport in the boundary current at $53^{\circ} \mathrm{N}$ are highly correlated with zero lag (Figures $17 \mathrm{~b}$ and 18 , the coefficient of 0.73 and 0.79 is significant on $98 \%$ and $99 \%$ level, respectively). This is an important result, suggesting that the SSH in the central Labrador Sea is a good indication of the SPNA circulation on a decadal time scale. Measuring the transport or water properties of the boundary current over a long-term scale is challenging. High quality
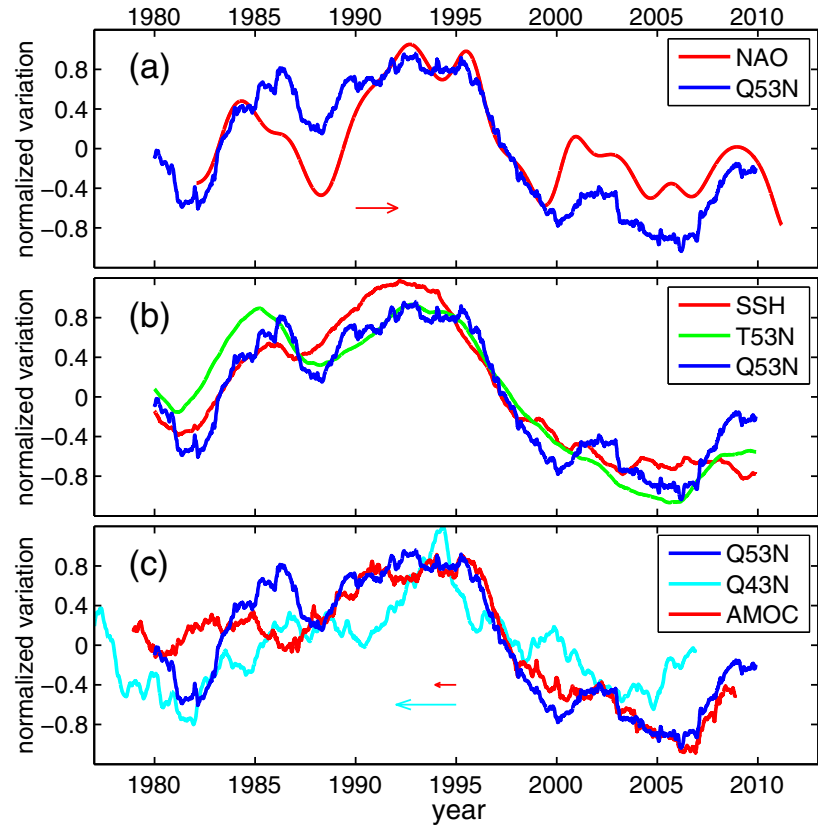

Figure 17. Normalized variation of the modeled boundary transport (Q) near $53^{\circ} \mathrm{N}$ in comparison to (a) the observed winter time NAO index, (b) the model-based SSH (inverted) in the central Labrador Sea and average potential temperature ( $\mathrm{T}$, inverted) of the boundary current at $53^{\circ} \mathrm{N}$, and (c) the modeled AMOC transport across the AR19 line and boundary transport at $43^{\circ} \mathrm{N}$. All results are 4 year running averaged. Horizontal arrows indicate the time lag as determined by cross-correlation (Figure 18).

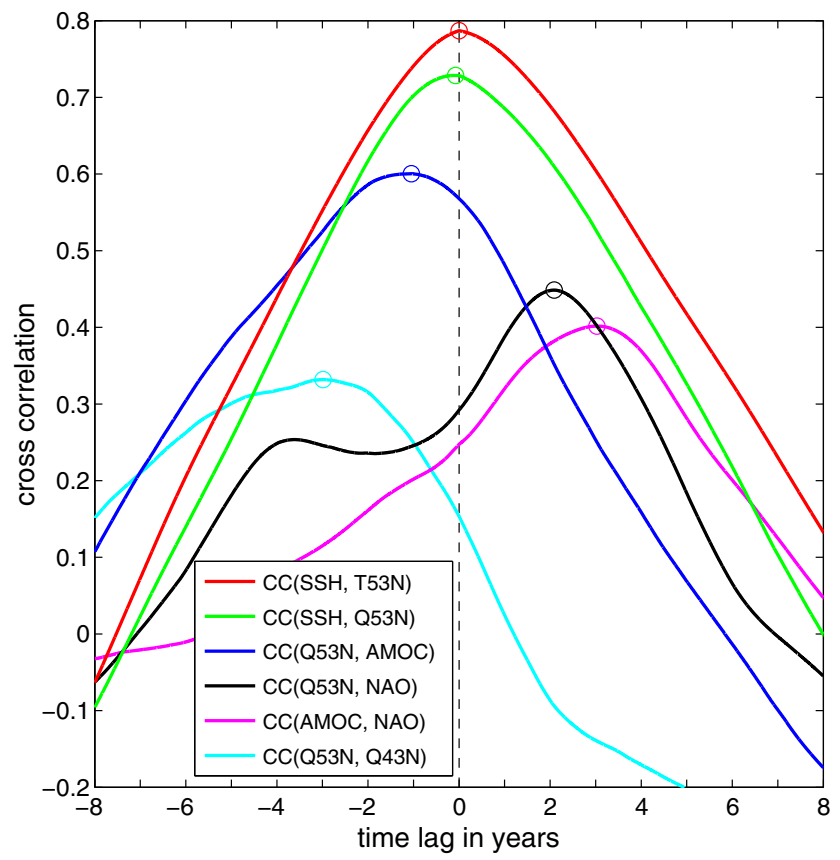

Figure 18. Cross-correlation of the long-term variations among the observed NAO index, model-determined $\mathrm{SSH}$ in the central Labrador Sea, boundary transports at $53^{\circ} \mathrm{N}$ and $43^{\circ} \mathrm{N}$, average potential temperature at $53^{\circ} \mathrm{N}$, and the AMOC transport across the AR19 section. Positive time lag indicates that the second variable is leading the first. 
SSH data from satellite altimeters, with fairly good temporal resolution $(\sim 10$ days), have been available since the early 1990s. Also, this result suggests that lower resolution models, having the advantage of very long integration but not resolving the boundary current, may use SSH as an index for SPNA transport (one needs to be cautious, however, that the relationship may differ when eddy dynamics are not resolved).

[32] Finally, the results show that the boundary current transport at $53^{\circ} \mathrm{N}$ is correlated with the AMOC transport across the AR19 section with a time lag of about 1 year (382 days, boundary transport leading). The overall correlation coefficient is 0.60 (significant on $95 \%$ level), but a higher correlation is obvious in the latter 25 years of the time series (Figure 17c). Generally, the model results suggest that, on a decadal time scale, there is a positive response of the AMOC transport to atmospheric conditions that are described by the NAO with a time lag of about 3 years. The response is connected via the boundary current in the western SPNA, specifically in LSW layer (Figure 9). Our model solution is similar to the results of Biastoch et al. [2008]. The different model formulations (e.g., vertical coordinate) and configurations (e.g., horizontal resolution and surface forcing) used here add model robustness and confidence, given the generally consistent temperature variation as well as time-mean transports in our model, to the indication of a predominately linear nature of the AMOC response to atmospheric forcing variability on $\sim$ decadal time scales.

\section{Summary and Conclusions}

[33] The SPNA Ocean is a key region relevant to climate because of its role in the formation and modification of LSW and NSOW, which constitute the lower limb of the AMOC. It has been well documented that the water masses in this area have undergone substantial long-term changes over past decades. However, much less is known observationally about associated changes in transports. In this study, we have used results from an interannually forced, eddyresolving OGCM simulation using HYCOM, in comparison with key observations, as a starting point toward resolution of the remaining transport questions for the composite $\mathrm{AMOC}$ in this area.

[34] The model results suggest that the western boundary current and the trans-basin AMOC in the SPNA both exhibit no systematic trend over the 34 years of integration (1978-2011). Long-term variability (interannual and longer) is present, including a decadal variation of about 3-4 Sv (Figures 7 and 13) as a lagged response to the NAO (section 5). However, the transports in the SPNA are dominated by variability on short-time scales (less than a year). The annual mean AMOC transports across the AR19 section, for example, have a standard deviation of $1.7 \mathrm{~Sv}$, compared to 3.8 and 6.7 $\mathrm{Sv}$ for monthly and daily means. Similarly, for the western boundary current near $53^{\circ} \mathrm{N}$, the annual, monthly, and daily mean transports exhibit standard deviations of 2.5, 5.0, and $7.9 \mathrm{~Sv}$, respectively. In general, these results are consistent with current measurements along the western boundary near $53^{\circ} \mathrm{kN}$ and $43^{\circ} \mathrm{N}$ [Fischer et al., 2004, 2010; Schott et al., 2004, 2006]. The currents observed at these two locations may be best characterized as very energetic at intraseasonal frequencies, but significantly less variable at low frequencies. Similar characteristics are found in the AMOC transport across the subtropical North Atlantic as derived from moored data [Kanzow et al., 2007; Cunningham et al., 2007; Rayner et al., 2011] and model results [Xu et al., 2012]. These results highlight the importance of filtering out comparatively high frequencies in order to avoid aliasing into the lower frequency transports of interest [Kanzow et al., 2010].

[35] Key aspects of the model results considered here are approximately consistent with the observations. The modelbased, long-term mean AMOC transport of $16.4 \mathrm{~Sv}$ across the AR19 section is in close agreement with the $16.2 \mathrm{~Sv}$ derived from inverse calculations [Lumpkin et al., 2008]. A majority of the southward transport of the lower limb AMOC, 14.6 out of $16.4 \mathrm{~Sv}$, is carried by the DWBC. The remaining, together with water returned from the northward NAC, flows southward both over the MAR and through the basin east of the MAR (Figure 16). The model result demonstrating a strong DWBC contribution to the overall lower limb of the AMOC is consistent with distributions of water properties and tracers [Clarke et al., 1980, Figures 10 and 13; Schott et al., 2004, Figures 16 and 17].

[36] The model-determined mean transports of the boundary current at the exit of the Labrador Sea near $53^{\circ} \mathrm{N}(39.0 \mathrm{~Sv})$ and east of the Grand Banks near $43^{\circ} \mathrm{N}(15.9 \mathrm{~Sv})$ are similar to the results from moored current meter arrays [Fischer et al., 2004; Schott et al., 2004]. The model results also yield a generally consistent temperature variation in the western SPNA. The cold period during early 1990s and the following decade-long period of warming closely correspond to a period of extremely high NAO (1989-1995) and a shift toward lower, neutral to negative NAO (1996-2011) (Figures 5 and 17). The warming since the early 1990 s is also linked to an SSH increase in the central Labrador Sea and a decrease in boundary current transport as it exits the Labrador Sea. From about 1993 to 2000, the modeled boundary current transport near $53^{\circ} \mathrm{N}$ decreased about $7 \mathrm{~Sv}$, similar to the $7-10 \mathrm{~Sv}$ as estimated based on geostrophic currents using $\mathrm{SSH}$ data [Häkkinen and Rhines, 2004].

[37] Several improvements are needed for a better understanding of the transport variability in this challenging region. First, by design, the simulations considered here are basin scale, so influences from outside of the model domain, e.g., the Arctic Ocean, have been neglected. Second, within the SPNA area of interest, although the modeled temperature variation since the early 1990 s roughly agrees with observations, the representation of salinity variation is far more challenging (Figure 4). Salinity plays an important role in the wintertime deep convection in the Labrador Sea, which may impact the AMOC (However, Pickart and Spall [2007] suggested that the AMOC is not largely impacted by deep convection in the Labrador Sea based on the small $1 \mathrm{~Sv}$ overturning across the AR7W section during the years 1990-1997 corresponding to intense convection). Finally, as in other OGCMs, the vertical profile of the western boundary current connected to DSOW is not well represented. This impacts the vertical structure of the AMOC even in the subtropical North Atlantic [Xu et al., 2012].

[38] Acknowledgments. This work is a contribution to the project U. S.-GODAE: Global ocean prediction using the HYbrid Coordinate Ocean Model, funded under the National Ocean Partnership Program, and to the projects Global remote littoral forcing via deep water pathways (program element $601153 \mathrm{~N}$ ) and Full column mixing for numerical ocean models $(602435 \mathrm{~N})$, funded by the Office of Naval Research. The moored current 


\section{XU ET AL.: TRANSPORTS IN THE SPNA}

meter observations are supported by the German Research ministry contract 03F0605B and by the EU FP7 project THOR. The altimeter products were produced by Ssalto/Duacs and distributed by Aviso, with support from CNES (http://www.aviso.oceanobs.com/duacs). The simulations were performed on supercomputers at the Naval Oceanographic Office, Stennis Space Center, MS, and the U.S. Army Engineer Research and Development Center, Vicksburg, MS, using computer time provided by the U.S. Department of Defense High Performance Computing Modernization Program Dr. R. Lumpkin (NOAA/AMOL) kindly provided the inverse results for comparison. The authors thank E. J. Metzger and A. J. Wallcraft (NRL/ SSC) for the help in configuring numerical experiments. This is Naval Research Laboratory publication number NRL/JA/7304-11-0647, and it has been approved for public release.

\section{References}

Avsic, T., J. Karstensen, U. Send, and J. Fischer (2006), Interannual variability of newly formed Labrador Sea Water from 1994 to 2005 , Geophys. Res. Lett., 33, L21S02, doi:10.1029/2006GL026913.

Bacon, S. (1998), Decadal variability in the outflow from the Nordic Seas to the deep Atlantic Ocean, Nature, 394, 871-874.

Biastoch, A., C. W. Böning, J. Getzlaff, J.-M. Molines, and G. Madec (2008), Causes of interannual-decadal variability in the meridional overturning circulation of the midlatitude North Atlantic Ocean, J. Clim., 21, 6599-6615, doi:10.1175/2008JCLI2404.1.

Böning, C. W., M. Scheinert, J. Dengg, A. Biastoch, and A. Funk (2006), Decadal variability of subpolar gyre transport and its reverberation in the North Atlantic overturning, Geophys. Res. Lett., 33, L21S01, doi:10.1029/2006GL026906.

Bower, A. S., M. S. Lozier, S. F. Gary, and C. W. Böning (2009), Interior pathways of the North Atlantic meridional overturning circulation, Nature, 459, 243-247, doi:10.1038/nature07979.

Brandt, P., A. Funk, L. Czeschel, C. Eden, and C. W. Böning (2007), Ventilation and transformation of Labrador Sea Water and its rapid export in the Deep Labrador Current, J. Phys. Oceanogr., 37, 946-961.

Bryan, F. O., M. W. Hecht, and R. D. Smith (2007), Resolution convergence and sensitivity studies with North Atlantic circulation models. Part I: The western boundary current system, Ocean Model., 16(3-4), 141-159.

Carnes, M. R. (2009), Description and evaluation of GDEM-V3.0, Tech. Rep. NRL/ MR/7330-09-9165, Naval Research Laboratory, 21 pp, available at http://www7320. nrlssc.navy.mil/pubs.php.

Chanut, J., B. Barnier, W. Large, L. Debreu, T. Penduff, J. M. Molines, and P. Mathiot (2008), Mesoscale eddies in the Labrador Sea and their contribution to convection and restratification, J. Phys. Oceanogr., 38, 1617-1643.

Clarke, R. A., H. W. Hill, R. F. Reiniger, and B. A. Warren (1980), Current system south and east of the Grand Banks of Newfoundland, J. Phys. Oceanogr., 10, 25-65.

Clarke, R. A., R. M. Hendry, and I. Yashayaev (1998), A western boundary current meter array in the North Atlantic near $42^{\circ} \mathrm{N}$, Int. WOCE Newslett., $33,33-34$.

Cunningham, S. A., et al. (2007), Temporal variability of the Atlantic meridional overturning circulation at $26.5^{\circ} \mathrm{N}$, Science, 317, 935-938.

Daniault, N., H. Mercier, and P. Lherminier (2011), The 1992-2009 transport variability of the East Greenland-Irminger Current at $60^{\circ} \mathrm{N}$, Geophys. Res. Lett., 38, L07601, doi:10.1029/2011GL046863.

de Jong, M. F., H. M. van Aken, and R. S. P. K. Våge (2012), Convective mixing in the central Irminger Sea: 2002 - 2010, Deep Sea Res., Part I, 63, 36-51, doi:10.1016/j.dsr.2012.01.003

Dickson, R. R., I. Yashayaev, J. Meincke, B. Turrell, S. Dye, and J. Holfort (2002), Rapid freshening of the deep North Atlantic over the past four decades, Nature, 416, 832-837.

Dickson, R. R., et al. (2008), The overflow flux west of Iceland: variability, origins and forcing, in Arctic-Subarctic Ocean Fluxes: Defining the Role of the Northern Seas in Climate, edited by R. R. Dickson, J. Meincke, and P. Rhines, pp. 443-474, Springer, New York.

Fischer, J., F. A. Schott, and M. Dengler (2004), Boundary circulation at the exit of the Labrador Sea, J. Phys. Oceanogr., 34(7), 1548-1570.

Fischer, J., M. Visbeck, R. Zantopp, and N. Nunes (2010), Interannual to decadal variability of outflow from the Labrador Sea, Geophys. Res. Lett., 37, L24610, doi:10.1029/2010GL045321.

Häkkinen, S., and P. B. Rhines (2004), Decline of subpolar North Atlantic gyre circulation during the 1990s, Science, 304, 555-559, doi:10.1126/ science. 1094917.

Häkkinen, S., and P. B. Rhines (2009), Shifting surface currents in the northern North Atlantic Ocean, J. Geophys. Res., 114, C04005, doi: $10.1029 / 2008$ JC004883.

Han, G., and C. Tang (2001), Interannual variations of volume transport in the western Labrador Sea based on TOPEX/Poseidon and WOCE data, J. Phys. Oceanogr., 31(1), 199-211.
Han, G., K. Ohashi, N. Chen, P. Myers, N. Nunes, and J. Fischer (2010), Decline and partial rebound of the Labrador Current 1993-2004: Monitoring ocean currents from altimetric and CTD data, J. Geophys. Res., 115, C12012, doi:10.1029/2009JC006091.

Hansen, B., S. Østerhus, W. R. Turrell, S. Jønsson, H. Valdimarsson, H. Hátún, and S. M. Olsen (2008), The inflow of Atlantic water, heat, and salt to the Nordic seas across the Greenland-Scotland ridge, in Arctic-Subarctic Ocean Fluxes: Defining the Role of the Northern Seas in Climate, edited by R. R. Dickson, J. Meincke, and P. Rhines, pp. 15-43, Springer, New York.

Hátún, H., A. Sandø, H. Drange, B. Hansen, and H. Valdimarsson (2005), Influence of the Atlantic subpolar gyre on the thermohaline circulation, Science, 309(5742), 1841-1844.

Holliday, N. P., et al. (2008), Reversal of the 1960s to 1990s freshening trend in the northeast North Atlantic and Nordic Seas, Geophys. Res. Lett., 35, L03614, doi:10.1029/2007GL032675.

Hurlburt, H. E., and P. J. Hogan (2000), Impact of $1 / 8^{\circ}$ to $1 / 64^{\circ}$ resolution on Gulf Stream model-data comparisons in basin-scale subtropical Atlantic Ocean models, Dyn. Atmos. Ocean, 32, 283-329.

Hurlburt, H. E., and P. J. Hogan (2008), The Gulf Stream pathway and the impacts of the eddy-driven abyssal circulation and the Deep Western Boundary Current, Dyn. Atmos. Ocean, 45, 71-101.

Hurlburt, H. E., et al. (2011), Dynamical evaluation of ocean models using the Gulf Stream as an example, in Operational Oceanography in the $21^{\mathrm{st}}$ Century, edited by A. Schiller, and G. B. Brassington, pp. 545-609, Springer, New York.

Hurrell, J. W. (1995), Decadal trends in the North Atlantic Oscillation: Regional temperatures and precipitation, Science, 269(5224), 676-679.

Kanzow, T., et al. (2007), Observed flow compensation associated with the $\mathrm{MOC}$ at $26.5^{\circ} \mathrm{N}$ in the Atlantic, Science, 317, 938-941.

Kanzow, T., et al. (2010), Seasonal variability of the Atlantic meridional overturning circulation at $26.5^{\circ} \mathrm{N}, J$. Climate, 23(21), 5678-5698, doi:10.1175/2010JCL13389.1.

Kara, A. B., H. E. Hurlburt, and A. J. Wallcraft (2005), Stability-dependent exchange coefficients for air-sea fluxes, J. Atmos. Oceanic Technol, 22(7), 1080-1094.

Kieke, D., and M. Rhein (2006), Variability of the overflow water transport in the western subpolar North Atlantic, 1950-97, J. Phys. Oceanogr., 36, 435-456, doi:10.1175/JPO2847.1.

Kieke, D., M. Rhein, L. Stramma, W. M. Smethie Jr., J. L. Bullister, and D. A. LeBel (2007), Changes in the pool of Labrador Sea Water in the subpolar North Atlantic, Geophys. Res. Lett., 34, L06605, doi:10.1029/ 2006GL028959.

Lazier, J. R. N., R. Hendry, A. Clarke, I. Yashayaev, and P. Rhines (2002), Convection and restratification in the Labrador Sea, 1990-2000, Deep Sea Res., Part I, 49, 1819-1835.

LeBel, D. A., et al. (2008), The formation rate of North Atlantic Deep Water and Eighteen Degree Water calculated from CFC-11 inventories observed during WOCE, Deep-Sea Res., Part I, 55(8), 891-910, doi:10.1016/j. dsr.2008.03.009.

Lherminier, P., H. Mercier, T. Huck, C. Gourcuff, F. F. Perez, P. Morin, A. Sarafanov, and A. Falina (2010), The Atlantic meridional overturning circulation and the subpolar gyre observed at the A25-OVIDE section in June 2002 and 2004, Deep Sea Res., Part I, 57, 1374-1391, doi:10.1016/j.dsr.2010.07.009.

Lohmann, K., H. Drange, and M. Bentsen (2009), A possible mechanism for the strong weakening of the North Atlantic subpolar gyre in the mid1990s, Geophys. Res. Lett., 36, L15602, doi:10.1029/2009GL039166.

Lozier, M. S. (2010), Deconstructing the conveyor belt, Science, 328, $1507-1511$

Lumpkin, R., K. G. Speer, and K. P. Koltermann (2008), Transport across $48^{\circ} \mathrm{N}$ in the Atlantic Ocean, J. Phys. Oceanogr., 38, 733-752, doi:10.1175/JPO3636.1.

Meinen, C. S. (2001), Structure of the North Atlantic Current in streamcoordinates and circulation in the Newfoundland Basin, Deep Sea Res., Part I, 48, 1553-1580.

Pickart, R. S., and M. A. Spall (2007), Impact of Labrador Sea convection on the North Atlantic meridional overturning circulation, J. Phys. Oceanogr., 37, 2207-2227.

Rattan, S., P. Myers, A. Treguier, S. Theetten, A. Biastoch, and C. Böning (2010), Towards an understanding of Labrador Sea salinity drift in eddypermitting simulations, Ocean Model., 35(1-2), 77-88.

Rayner, D., et al. (2011), Monitoring the Atlantic meridional overturning circulation, Deep Sea Res. Part II, 58(17), 1744-1753, doi:10.1016/j. dsr2.2010.10.056.

Rhein, M., D. Kieke, S. H. Kabus, A. Roessler, C. Mertens, R. Meissner, C. W. Böning, and I. Yashayaev (2011), Deep water formation, the subpolar gyre, and the meridional overturning circulation in the subpolar North Atlantic, Deep Sea Res., Part II, 58, 1819-1832, doi:10.1016 j.dsr2.2010.10.061. 


\section{XU ET AL.: TRANSPORTS IN THE SPNA}

Rosmond, T., J. Teixeira, M. Peng, T. Hogan, and R. Pauley (2002), Navy Operational Global Atmospheric Prediction System (NOGAPS): Forcing for ocean models, Oceanogr., 15(1), 99-108.

Sarafanov, A., A. Sokov, A. Demidov, and A. Falina (2007), Warming and salinification of intermediate and deep waters in the Irminger Sea and Iceland Basin in 1997-2006, Geophys. Res. Lett., 34, L23609, doi:10.1029/2007GL031074.

Sarafanov, A., A. Falina, A. Sokov, and A. Demidov (2008), Intense warming and salinification of intermediate waters of southern origin in the eastern subpolar North Atlantic in the 1990s to mid-2000s, J. Geophys. Res., 113, C12022, doi:10.1029//2008JC004975.

Sarafanov, A., A. Falina, H. Mercier, P. Lherminier, and A. Sokov (2009), Recent changes in the Greenland-Scotland overflow derived water transport inferred from hydrographic observations in the southern Irminger Sea, Geophys. Res. Lett., 36, L13606, doi:10.1029/2006GL038385.

Sarafanov, A., A. Falina, P. Lherminier, H. Mercier, A. Sokov, and C. Gourcuff (2010), Assessing decadal changes in the Deep Western Boundary Current absolute transport southeast of Cape Farewell, Greenland, from hydrography and altimetry, J. Geophys. Res., 115, C11003, doi:10.1029/2009JC005811

Sarafanov, A., A. Falina, H. Mercier, A. Sokov, P. Lherminier, C. Gourcuff, S. Gladyshev, F. Gaillard, and N. Daniault (2012), Mean full-depth summer circulation and transports at the northern periphery of the Atlantic Ocean in the 2000s, J. Geophys. Res., 117, C01014, doi:10.1029/ 2011JC007572.

Schott, F., L. Stramma, R. Zantopp, M. Dengler, J. Fischer, and M. Wibaux (2004), Circulation and deep water export at the western exit of the subpolar North Atlantic, J. Phys. Oceanogr., 34(4), 817-843.

Schott, F. A., and P. Brandt (2007), Circulation and deep water export of the subpolar North Atlantic during the 1990's, in Ocean Circulation: Mechanisms and Impacts, edited by A. Schmittner, J. C. Chiang, and S. R. Hemming, pp. 91-118, AGU, Washington, DC.

Schott, F. A., J. Fischer, M. Dengler, and R. Zantopp (2006), Variability of the Deep Western Boundary Current east of the Grand Banks, Geophys. Res. Lett., 33, L21S07, doi:10.1029/2006GL026563.

Smethie Jr., W. M., and R. A. Fine (2001), Rates of North Atlantic Deep Water formation calculated from chlorofluorocarbon inventories, Deep Sea Res., Part I, 48, 189-215.
Stramma, L., D. Kieke, M. Rhein, F. Schott, I. Yashayaev, and K. P. Koltermann (2004), Deep water changes at the western boundary of the subpolar North Atlantic during 1996 to 2001, Deep Sea Res., Part I, 51, 1033-1056, doi:10.1016/j.dsr.2004.04.001.

Treguier, A. M., S. Theetten, E. P. Chassignet, T. Penduff, R. Smith, L. Talley, J. O. Beismann, and C. Böning (2005), The North Atlantic subpolar gyre in four high-resolution models, J. Phys. Oceanogr., 35, 757-774.

Uppala, S. M., et al. (2005), The ERA-40 re-analysis, Quart. J. R. Meteorol. Soc., 131, 2961-3012, doi:10.1256/qj.04.176.

Våge, K., R. Pickart, V. Thierry, G. Reverdin, C. Lee, B. Petrie, T. Agnew, A. Wong, and M. Ribergaard (2009), Surprising return of deep convection to the subpolar North Atlantic Ocean in winter 2007-2008, Nat. Geosci., 2(1), 67-72, doi:10.1038/ngeo382.

Willis, J. (2010), Can in situ floats and satellite altimeters detect long-term changes in Atlantic Ocean overturning, Geophys. Res. Lett., 37(6), L06602, doi:10.1029/2010GL042372.

Xu, X., W. J. Schmitz Jr., H. E. Hurlburt, P. J. Hogan, and E. P. Chassignet (2010), Transport of Nordic Seas overflow water into and within the Irminger Sea: An eddy-resolving simulation and observations, J. Geophys. Res., 115, C12048, doi:10.1029/2010JC006351.

Xu, X., W. J. Schmitz Jr., H. E. Hurlburt, and P. J. Hogan (2012), Mean Atlantic meridional overturning circulation across $26.5^{\circ} \mathrm{N}$ from eddyresolving simulations compared to observations, J. Geophys. Res., 117, C03042, doi:10.1029/2011JC007586.

Yashayaev, I. (2007), Hydrographic changes in the Labrador Sea, 1960-2005, Prog. Oceanogr., 73, 242-276.

Yashayaev, I., and J. Loder (2009), Enhanced production of Labrador Sea Water in 2008, Geophys. Res. Lett., 36(1), L01606, doi:10.1029/2008GL036162.

Yoshimori, M., C. Raible, T. Stocker, and M. Renold (2010), Simulated decadal oscillations of the Atlantic meridional overturning circulation in a cold climate state, Clim. Dyn., 34(1), 101-121, doi:10.1007/s00382009-0540-9.

Zhang, R. (2008), Coherent surface-subsurface fingerprint of the Atlantic meridional overturning circulation, Geophys. Res. Lett., 35, L20705, doi:10.1029/2008GL035463.

Zhu, J., and E. Demirov (2011), On the mechanism of interannual variability of the Irminger Water in the Labrador Sea, J. Geophys. Res., 116(C3), C03014, doi:10.1029/2009JC005677. 